\title{
The Long-Term Monitoring of Bird Populations on Kolguev Island in the Barents Sea
}

\author{
Petr M. Glazov, ${ }^{1,2}$ Julia A. Loshchagina, ${ }^{1}$ Alexander V. Kondratyev, ${ }^{3}$ Elmira M. Zaynagutdinova, ${ }^{4}$ \\ Helmut Kruckenberg ${ }^{5}$ and Ivan G. Pokrovsky ${ }^{3,6,7}$
}

(Received 1 October 2020; accepted in revised form 18 June 2021)

\begin{abstract}
Kolguev Island $\left(69^{\circ} 05^{\prime} \mathrm{N} 49^{\circ} 15^{\prime} \mathrm{E}\right)$ is located in the Pechora Sea, the southeastern part of the Barents Sea. The island's ecosystem is unusual due to the total absence of rodents and specialized predators such as weasels, while non-specialized predators such as Arctic (Vulpes lagopus) and red (V. vulpes) foxes and Rough-legged Hawk (Buteo lagopus) are common. Currently, 111 bird species have been registered here, of which 58 are nesting. The absence of rodents and the relatively stable predation pressure have resulted in the high abundance of many bird species: Willow Ptarmigan (Lagopus lagopus), several goose species, some waders, and passerines. Over the 125-year history of ornithological studies on Kolguev, the island avifauna has changed significantly. The trend of an increase in the proportion of widespread and Siberian species together with a decrease in the proportion of Arctic species was observed. Since 2006, a thorough monitoring of Kolguev avifauna has been carried out, during which the dynamics of the bird population densities have been traced. The abundance of Black-bellied Plover (Pluvialis squatarola) and Dunlin (Calidris alpina) decreased, while the numbers of Barnacle Goose (Branta leucopsis) have increased sharply since the 1980s. The breeding density of Rough-legged Hawk has also increased in recent years. The long-term monitoring of Kolguev ecosystems has indicated the high international conservation value of the island due to the high breeding density of many bird species. Our study, covering more than a century of avifaunal studies with almost annual monitoring over the past three decades, provides an unusually long and detailed time-series for an Arctic island.
\end{abstract}

Key words: Russian Arctic; Arctic birds; Kolguev Island; population density; population trends; long-term Arctic monitoring; Barents Sea; tundra avifauna; waders; geese

RÉSUMÉ. L'île de Kolgouev (69 $05^{\prime}$ N 49 $15^{\prime}$ E) se situe dans la mer de Pechora, dans la partie sud-est de la mer de Barents. L'écosystème de l'île est inhabituel en raison de l'absence totale de rongeurs et de prédateurs spécialisés comme la belette, tandis que les prédateurs non spécialisés comme le renard arctique (Vulpes lagopus), le renard roux ( $V$. vulpes) et la buse pattue (Buteo lagopus) sont communs. À présent, 111 espèces d'oiseaux ont été enregistrées ici, dont 58 y nichent. L'absence de rongeurs et la pression relativement stable exercée par les prédateurs ont donné lieu à la grande abondance de nombreuses espèces d'oiseaux, soit les lagopèdes des saules (Lagopus lagopus), plusieurs espèces d'oies, certains échassiers et des passereaux. Au cours de l'histoire des études ornithologiques de Kolgouev échelonnée sur 125 ans, la faune aviaire de l'île a changé considérablement. On y observe une tendance vers l'augmentation de la proportion d'espèces répandues et d'espèces sibériennes, et vers la diminution de la proportion d'espèces de l'Arctique. Depuis 2006, la faune aviaire de l'île de Kolgouev a fait l'objet d'une surveillance rigoureuse, ce qui a permis de tracer la dynamique des densités des populations d'oiseaux. L'abondance de pluviers argentés (Pluvialis squatarola) et de bécasseaux variables (Calidris alpina) a diminué, tandis que le nombre de bernaches nonnettes (Branta leucopsis) s'est accru brusquement depuis les années 1980. Par ailleurs, la densité de reproduction de la buse pattue a augmenté ces dernières années. La surveillance à long terme des écosystèmes de Kolgouev témoigne de la forte valeur de conservation de cette île à l'échelle internationale en raison de la densité de reproduction de nombreuses espèces d'oiseaux. Notre étude, qui porte sur plus d'un siècle d'études de la faune aviaire ayant fait l'objet de travaux de surveillance quasi annuels au cours des trois décennies, fournit une série chronologique inhabituellement longue et détaillée pour une île de l'Arctique.

Mots clés : Arctique russe; oiseaux de l'Arctique; île de Kolgouev; densités des populations; tendances des populations; surveillance de l'Arctique à long terme; mer de Barents; faune aviaire de la toundra; échassiers; oies

Traduit pour la revue Arctic par Nicole Giguère.

\footnotetext{
${ }^{1}$ Institute of Geography, Russian Academy of Sciences, Staromonetniy pereulok, 29, Moscow, 119017, Russia

${ }^{2}$ Corresponding author: glazpech@gmail.com

${ }^{3}$ Institute of Biological Problems of the North, Far Eastern Branch of the Russian Academy of Sciences (IBPN FEB RAS), Portovaya Str., 18, Magadan, 685000, Russia

${ }^{4}$ St.-Petersburg State University, Universitetskaya Emb., 7-9, St.-Petersburg, 199034, Russia

${ }^{5}$ Institute for Wetlands and Waterfowl Research (IWWR) e.V., Am Steigbügel 13; 27283 Verden (Aller), Germany

${ }^{6}$ Department of Migration, Max Planck Institute of Animal Behavior, Am Obstberg 1, 578315 Radolfzell, Germany

${ }^{7}$ Institute of Plant and Animal Ecology, Ural Division Russian Academy of Sciences, 8 Marta Str. 202/3, Yekaterinburg, 620144, Russia

(C) The Arctic Institute of North America
} 


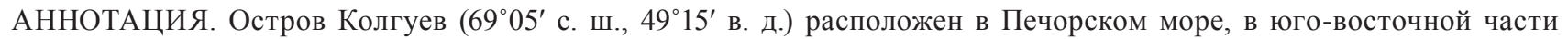
Баренцева моря. Экосистема острова нетипична ввиду полного отсутствия грызунов и таких специализированных миофагов, как мелкие куньи. В то же время на острове обычны такие неспециализированные хищники, как песец (Vulpes lagopus) и обыкновенная лисица ( . vulpes), а также не менее характерным обитателем острова является зимняк (Buteo lagopus). В настоящее время здесь зарегистрировано 111 видов птиц из них 58 гнездящихся. Отсутствие грызунов и относительно стабильный пресс хищников привели к высокой численности многих видов птиц: белой куропатки (Lagopus lagopus), нескольких видов гусей, некоторых куликов и воробьиных. За более чем столетнюю историю орнитологических исследований на острове Колгуев орнитофауна острова претерпела существенные изменения. Наблюдается тенденция к увеличению доли широкоареальных и сибирских видов при уменьшении доли арктических видов. С 2006 года проводится тщательный мониторинг орнитофауны Колгуева, в течение которого удалось проследить динамику плотности населения птиц. Численность некоторых куликов (тулес (Pluvialis squatarola), чернозобик (Calidris alpina)) снизилась, в то время как численность белощекой казарки (Branta leucopsis) резко возросла с первой регистрации гнездования этого вида на острове в 1980-х гг. В последние годы также существенно увеличилась плотность гнездования зимняка. Долговременный мониторинг экосистем Колгуева показал высокую международную природоохранную ценность острова из-за высокой плотности гнездования многих видов птиц. Наше исследование, охватывающее более чем вековой период орнитологических исследований с почти ежегодным мониторингом в течение последних трех десятилетий, обеспечивает необычайно длинные и подробные временные ряды для арктического острова.

Российская Арктика, птицы Арктики, остров Колгуев, плотность населения, тренды численности, долговременный мониторинг арктических экосистем, Баренцево море, орнитофауна тундры, кулики, гуси

\section{INTRODUCTION}

Arctic ecosystems are extremely sensitive to anthropogenic pressure and climate changes (Meredith et al., 2019). Rapid changes in climate alongside increases in industrial exploration of the Arctic regions have led to significant changes in the Arctic ecosystems over recent decades (Schindler and Smol, 2006; Gilg et al., 2009, 2012). Climate change presumably leads to the modifications of both terrestrial and oceanic ecosystems. Lemming cycles, which were the basis of most terrestrial ecosystems of the Arctic, have collapsed since 1995 (Ims et al., 2008; Kausrud et al., 2008). As a result, the predator pressure on nesting birds, their eggs, and their offspring has probably increased (Ims and Fuglei, 2005). In addition, climate change also leads to rising water temperatures and a decrease in the ice cover, thereby changing the composition of phytoplankton communities, the basis of aquatic food webs (Smol et al., 2005). Moreover, increased shipping traffic as well as oil and gas exploration add additional pressures on the species inhabiting the Arctic zone (Reeves et al., 2014).

Despite its harsh environment, the Arctic is populated by roughly 200 bird species (Ganter and Gaston, 2013). Arctic breeding birds benefit from greater food availability due to longer daylight hours (Schekkerman et al., 2003; Pokrovsky et al., 2021), reduced parasite loads (Bennett et al., 1992; Kutz et al., 2005), and the relative safety from predation created by continuous daylight, low diversity of predators, and the sheer numbers of prey swamping the predator pressure (McKinnon et al., 2010). In response to extreme seasonality, most birds leave the Arctic after the breeding season and spend more than half a year in warmer climate zones (Ganter and Gaston, 2013) where they face other limiting factors. For example, it was shown that goose populations are more limited by factors on their wintering grounds than on tundra habitats (van Eerden et al., 2005). Thus, sustainable agriculture and hunting regulations in the second part of the 20th century led to an increase in Arctic goose population numbers in Europe (Ebbinge, 1991; MacMillan et al., 2004; Fox and Leafloor, 2018), while population growth of Ross's Goose (Anser rossii) and Snow Goose (A. caerulescens) resulted in soil cover degradation in tundra (Alisauskas et al., 2006).

Our study was conducted on Kolguev Island, located in the Pechora Sea, the southeastern part of the Barents Sea. Kolguev's ecosystem is quite rare due to the total absence of rodents on the island. Research on lemmingfree Arctic ecosystems makes it possible to separate the impact of the lemming cycle collapse from the impact of other factors on Arctic ecosystem dynamics. Alongside lemmings, specialized predators such as weasels are also absent on Kolguev, while non-specialized predators are common, such as Arctic fox (Vulpes lagopus), red fox ( $V$. vulpes), and Rough-legged Hawk (Buteo lagopus), which are dependent on lemming cycles in other parts of the Arctic but demonstrate different trophic connections within the Kolguev ecosystem (Pokrovsky et al., 2015). In general, Kolguev avifauna is characterized by exceptionally high abundances of certain species such as Willow Ptarmigan (Lagopus lagopus), Greater White-fronted Goose (Anser albifrons), Tundra Bean Goose (Anser fabalis rossicus), Barnacle Goose (Branta leucopsis), and some wader species (Morozov and Syroechkovsky, 2004). Willow Ptarmigan, geese, and semidomestic reindeer (Rangifer tarandus) are the main consumers of vegetation on the island. The latter two are known to act as powerful inhibitors of the development of moss cover via the pasture load and the associated trampling effect, which contributes to the spread, development, and increase in productivity of grass communities that are an important food source for them (van der Wal et al., 2006). 
Our study aimed at tracing the abundance dynamics of several bird species on Kolguev Island over the period between 2006 and 2019. Since the first expedition to Kolguev of Trevor-Battye in 1894 (Trevor-Battye, 1895), ornithological studies have been carried out on the island from time to time, but most of these were short-term and unsystematic (Pearson, 1896; Zhitkov and Buturlin, 1901; Buturlin, 1903; Tolmachev, 1927; Pleske, 1928; Ponomareva, 1990; Gavrilo, 1991; Anufriev, 2006, 2012a; Krasnov et al., 2008; Potapov and Spitsyn, 2019). In 1994-95, the first comprehensive studies covering the whole breeding season were conducted by Morozov and Syroechkovsky (2004). Our study was initiated 10 years later and became the first long-term research that resulted in complete data on the abundances of bird species on the island and their population dynamics over the 21 st century.

\section{MATERIALS AND METHODS}

\section{Study Area}

Kolguev Island is located in the southeastern part of the Barents Sea between $68^{\circ} 41^{\prime}$ and $69^{\circ} 30^{\prime} \mathrm{N}$, and $48^{\circ} 12^{\prime}$ and $50^{\circ} 18^{\prime} \mathrm{E}$ and is separated from the mainland by the $70-80$ $\mathrm{km}$ wide Pomor Strait (Fig. 1). The width of the island is 83 $\mathrm{km}$ from east to west, and its length is $93 \mathrm{~km}$ from north to south, with a total area of $5020 \mathrm{~km}^{2}$. The average height of the island's surface above sea level is $20-60 \mathrm{~m}$; in the elevated area, the altitude reaches $140-173 \mathrm{~m}$. The southern part of Kolguev is a flat plain with a height of 4-6 $\mathrm{m}$. The coastline of the island is little indented; the coast is gentle in the east and steep and high in the west. Kolguev has mild winters and cool summers. The average daily temperatures exceed $0^{\circ} \mathrm{C}$ by the end of May.

The northern, western, and central parts of Kolguev are classified as the typical tundra subzone, while the vegetation communities of the southern and eastern parts belong to the southern tundra subzone (Gribova, 1980). The island is dominated by slightly hummocky, mosslichen tundra. Bogs occupy $38 \%$ of the island. Sedge and cotton grass bogs are common in the river valleys. The southern coastal lowlands are particularly rich in bogs (Bogdanovskaya-Gienef, 1938).

Kolguev has a well-developed river and lake system. The rivers are fed by snow. Most of the lakes on the island are shallow thermokarst lakes, which freeze to the bottom in winter. Deeper glacial lakes with sandy shores occur in the higher part of the island. The largest river is the Peschanka, which is $150 \mathrm{~km}$ long and crosses the island from northwest to southeast. The surface of the island is indented by gullies with vegetated slopes. The river valleys are deep with abrupt banks except for the estuary part of the Peschanka River, which forms a large wide delta near the inflow to the sea (Koreisha, 2000). Sedge fens, hummocky tundra, and floodplain willow shrubs are common in the river valleys. The height of the willows reaches $70-100 \mathrm{~cm}$ (Gribova, 1980).
There is a settlement in the southeast of Kolguev with a population of about 450 people. The main land use on Kolguev is reindeer herding. In 2012, the number of reindeer was about 12,000 , but mass mortality of reindeer in winter 2013-14 left about 200 reindeer. The current reindeer population is approximately 1000 individuals. In general, reindeer grazing and regular movements of herding teams were a significant factor of anthropogenic disturbance over large areas until 2014, while these days anthropogenic pressures are more locally concentrated around the village.

\section{Study Dates and Locations}

The fieldwork expeditions were carried out by a team of 3-14 people on 29 May-13 August 2006, 24 May-16 August 2007, 29 May-10 September 2008, 28 May-11 August 2011, 1 June-2 August 2012, 29 June-6 July 2015, 9 June-12 August 2017, 9 June-14 August 2018, and 6 June-14 August 2019. Most of the study periods included the whole breeding and post-breeding periods.

In 2006, base camp was by the Lower Peschanka River in the east of the island $\left(69^{\circ} 07.693^{\prime} \mathrm{N}, 49^{\circ} 57.694^{\prime} \mathrm{E}\right)$, in 2007-08 it was in the central part of the island at the middle reaches of the Peschanka River $\left(69^{\circ} 10.52^{\prime} \mathrm{N}, 48^{\circ} 54.745^{\prime} \mathrm{E}\right)$, in 2011-12 and 2015 the base camp was by the Upper Peschanka River $\left(69^{\circ} 14.636^{\prime} \mathrm{N}, 48^{\circ} 50.636^{\prime} \mathrm{E}\right.$ in $2011-12$ and $69^{\circ} 15.670^{\prime} \mathrm{N}, 48^{\circ} 56.589^{\prime} \mathrm{E}$ in 2015); in 2017-19, base camp was in the same place as in 2007-08. The main study areas were located near the base camps, but the route counts were carried out in all parts of the island (Fig. 1).

\section{Study Methods}

Bird counts were carried out using the method of route census according to a standard protocol with a non-fixed width of the counting zone and recording the distance to the bird (Ravkin and Chelintsev, 1990). The estimation of the population density for each species in individuals per $1 \mathrm{~km}^{2}$ $D_{i}$ was calculated according to Kuzyakin and Chelintsev (2005) by the formula:

$$
D_{i}=\frac{n}{2 L_{i} B}, B=k / \sum_{i=1}^{k} \frac{1}{r_{i}},
$$

where $n$ is the total number of birds observed (individuals), $L_{i}$ is the length of the counting route $(\mathrm{km}), B$ is the effective width of the counting band on one side of the route $(\mathrm{km})$, $k$ is the number of detected groups of birds (number of observations), and $r_{i}$ is a radial detection distance at a specific observation $(\mathrm{km})$. For flying birds, counting time $T$ (h) multiplied by the estimated flight speed $(\mathrm{km} / \mathrm{h})$ was used instead of route length $L$ in this formula (Kuzyakin and Chelintsev, 2005). The final density for each route count was calculated as a sum of these two densities. The average density of each species for the current year was calculated using the formula: 


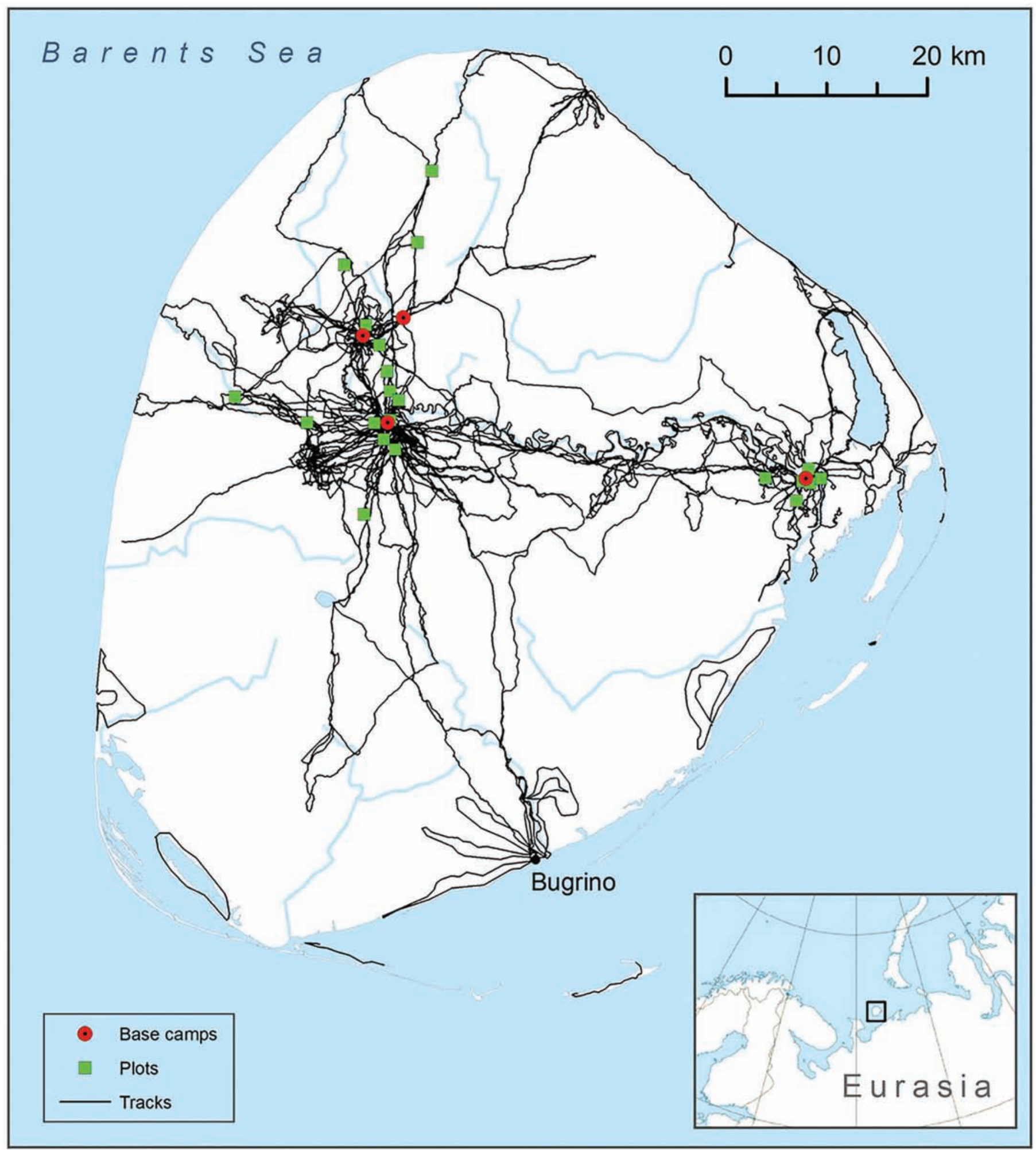

FIG. 1. Location of Kolguev Island and exploration of the island from 2006 to 2019. The red dots mark the locations of the expedition camps. Black lines indicate tracks, some of which were used for the route censuses. Green squares indicate plots for counting the nesting density of geese.

$$
D=\frac{\sum\left(D_{i} \times L_{i}\right)}{L},
$$

where $D_{i}$ is the density of each bird species (ind. $/ \mathrm{km}^{2}$ ) on the counting route, $L_{i}$ is the length of the counting route $(\mathrm{km})$, and $L$ is the total length of the counting routes for the current year $(\mathrm{km})$. The route counts were carried out during the pre-nesting and nesting periods (June to the first week of July), and the timing of the counts did not differ between years to avoid variation in bird detectability (see 
e.g., Meltofte, 2001). During censuses, only adult birds were counted, flocks and concentrations were not included. In total, 58 route censuses were conducted over a total distance of $768.8 \mathrm{~km}$.

Furthermore, the density of nesting geese was calculated using a complete count of nests on permanent square plots located in different biotopes. The coordinates of the plots were pre-marked using satellite images and maps. Plots were located in all main areas of the island within the homogeneous landforms. Within the plots, a total count of goose nests was carried out by two to six observers spaced $20 \mathrm{~m}$ apart and simultaneously moving back and forth in a line across the plot. The plot sizes varied between 0.22 and $0.47 \mathrm{~km}^{2}$. To compare the nesting density in different years, only plots from the central part of the island were used. There, a complete census of goose nests was conducted in a total of 14 plots.

For colonial breeding species, a complete nest survey was conducted within the colonies. The only exception was the biggest colony of Barnacle Goose in the Peschanka River delta, where the colony size was obtained via the nest counts along the $10 \mathrm{~m}$ wide transects, crossing various parts and habitats of the colony and separated from each other by $300-600 \mathrm{~m}$. The number of nests on the transects was then extrapolated for the various parts and habitats of the colony and summed for its overall area.

The complete counts of territorial pairs of birds of prey were carried out in the central part of the island. The core area was the same in all years, but the size ranged from 150 to $350 \mathrm{~km}^{2}$ in different years. In addition, complete counts of territorial pairs of some species (swans, large waders, skuas) were conducted in June 2019 over an area of $128.4 \mathrm{~km}^{2}$.

\section{Statistical Analysis}

Statistical analysis was performed using $\mathrm{R}$ software version 4.0.5 (R Core Team, 2021). Each species was analyzed separately. For each species, a set of its density data from all route censuses was used for the analysis. First, we visually analyzed the graphs of the dynamics of the average annual values for each species. According to these graphs, we selected species that showed directional trends in their population densities for statistical analysis, while species that showed no trends were considered stable and were not analyzed statistically. For the species that were subjected to statistical analysis, we used dotchart plots and histograms for visual analysis of data structure (Zuur et al., 2010). Values exceeding the mean value by more than 3.5 SD (standard deviations) were considered outliers and excluded from further analyses. To trace the dynamics of the population density of these species over the years, we used separate generalized linear models for each species. All density data were modeled with a Gamma distribution and log-link. Model fits were validated by a deviance goodness of fit test (Crawley, 2007) and visual estimation of deviance residual plots (Zuur et al., 2009), which had no signs of violation of underlying assumptions. In total, 12 models were performed to examine the dynamics of the population density of bird species. To control for the multiple comparisons, we used the Benjamini-Hochberg test to adjust the individual $p$-values to account for false discoveries (Benjamini and Hochberg, 1995).

For some species that showed significant trends in their population density, the interannual variance of the average annual population density was analyzed using analysis of variance (ANOVA). To normalize distributions, density data were square-root transformed. Pairwise comparisons between years were performed using the lsmeans function in the lsmeans package (Lenth, 2016). Post-hoc tests of differences between years based on ANOVA results were conducted using Duncan's multiple range test (Duncan, 1955) using the PostHocTest function in the DescTools package. In all cases, the level of significance was $p=0.05$.

The analysis of data on the breeding density of Greater White-fronted Goose and Tundra Bean Goose based on nest counts on the permanent plots was implemented using mixed-effect models (Zuur et al., 2009) by means of the lmer function in lme4 package (Bates et al., 2015). We included Year as a fixed factor in the models and Plot ID as a random factor since the same plots were used in different years. Again, pairwise comparisons between the years were performed using the lsmeans function in the lsmeans package (Lenth, 2016).

\section{RESULTS}

In total, we identified 103 bird species, of which 57 species were recorded during the route censuses. The most abundant species were Greater White-fronted Goose, Lapland Longspur (Calcarius lapponicus), Willow Ptarmigan, Dunlin (Calidris alpina), Barnacle Goose, Meadow Pipit (Anthus pratensis), and Tundra Bean Goose (Table 1). The population densities of the other species were considerably less. The irregular occurrence of some species did not allow us to trace any dynamics in their density. The distribution of some species is extremely limited by spatial factors such as the vicinity of the sea (e.g., Red-throated Loon [Gavia stellata] and Ruddy Turnstone [Arenaria interpres]) or the location of colonies for colonial nesting species (e.g., Barnacle Goose). Since these factors insert some bias in the calculation of the average density for each year, we removed them from the analysis. Thus, only uniformly distributed tundra bird species and census routes located in the same parts of the island in similar landscapes were used in the analysis. Based on visual estimation of the dynamics of average annual density values, we selected 12 species that showed directional trends in their densities over the years. The results of modeling the density of these species are presented in Table 2.

Significant differences in the population density over the study period were observed for six species: Willow Ptarmigan, Greater Scaup (Aythya marila), Black-bellied 
TABLE 1. Population densities of the species inhabiting Kolguev Island according to route censuses conducted in 2006-19. The range of the average annual population density and the mean density for the study period are shown.

\begin{tabular}{|c|c|c|c|c|}
\hline \multirow[b]{2}{*}{ No. } & \multicolumn{2}{|c|}{ Species } & \multicolumn{2}{|c|}{ Population density (ind./ $\mathrm{km}^{2}$ ) } \\
\hline & English name & Latin name & Range & Mean \\
\hline 1 & Arctic Loon & Gavia arctica & $0.22-4.16$ & 1.21 \\
\hline 2 & Tundra Bean Goose & Anser fabalis rossicus & $3.93-20.46$ & 12.19 \\
\hline 3 & Greater White-fronted Goose & Anser albifrons & $51.51-91.91$ & 76.46 \\
\hline 4 & Tundra Swan & Cygnus columbianus bewickii & $0.24-1.1$ & 0.53 \\
\hline 5 & Northern Pintail & Anas acuta & $0.44-4.87$ & 2.23 \\
\hline 6 & Eurasian Teal & Anas crecca & $0.03-7.64$ & 1.68 \\
\hline 7 & Greater Scaup & Aythya marila & $0.48-8.82$ & 3.80 \\
\hline 8 & King Eider & Somateria spectabilis & $0.44-3.46$ & 1.55 \\
\hline 9 & Velvet Scoter & Melanitta fusca & $0.04-6.02$ & 1.64 \\
\hline 10 & Long-tailed Duck & Clangula hyemalis & $1.94-12.95$ & 7.51 \\
\hline 11 & Willow Ptarmigan & Lagopus lagopus & $12.37-96.72$ & 53.29 \\
\hline 12 & European Golden Plover & Pluvialis apricaria & $0.47-3.22$ & 1.36 \\
\hline 13 & Black-bellied Plover & Pluvialis squatarola & $0.12-7.37$ & 2.73 \\
\hline 14 & Common Ringed Plover & Charadrius hiaticula & $0.61-4.05$ & 2.95 \\
\hline 15 & Ruff & Calidris pugnax & $0.28-4.85$ & 1.69 \\
\hline 16 & Temminck's Stint & Calidris temminckii & $3.06-12.73$ & 5.38 \\
\hline 17 & Dunlin & Calidris alpina & $21.93-48.02$ & 32.49 \\
\hline 18 & Little Stint & Calidris minuta & $1.54-16.06$ & 4.85 \\
\hline 19 & Common Snipe & Gallinago gallinago & $0.16-7.5$ & 1.64 \\
\hline 20 & Red-necked Phalarope & Phalaropus lobatus & $0.56-11.11$ & 4.81 \\
\hline 21 & Wood Sandpiper & Tringa glareola & $0.63-2.42$ & 0.86 \\
\hline 22 & Parasitic Jaeger & Stercorarius parasiticus & $0.43-3.29$ & 1.35 \\
\hline 23 & Glaucous Gull & Larus hyperboreus & $0.17-2.41$ & 1.09 \\
\hline 24 & Horned Lark & Eremophila alpestris & $0.44-8.56$ & 3.02 \\
\hline 25 & Willow Warbler & Phylloscopus trochilus & $1.76-8.28$ & 2.51 \\
\hline 26 & Redwing & Turdus iliacus & $0.63-3.38$ & 1.01 \\
\hline 27 & Bluethroat & Luscinia svecica & $0.88-6.63$ & 1.69 \\
\hline 28 & Northern Wheatear & Oenanthe oenanthe & $0.2-3.66$ & 0.64 \\
\hline 29 & White Wagtail & Motacilla alba & $1.25-7.94$ & 3.44 \\
\hline 30 & Meadow Pipit & Anthus pratensis & $4.21-34.24$ & 14.48 \\
\hline 31 & Red-throated Pipit & Anthus cervinus & $0.67-18.4$ & 5.49 \\
\hline 32 & Common Redpoll & Acanthis flammea & $0.03-3.8$ & 0.98 \\
\hline 33 & Lapland Longspur & Calcarius lapponicus & $32.15-98.74$ & 72.12 \\
\hline
\end{tabular}

TABLE 2. Results of the Gamma generalized linear models of the changes in population density over the years for 12 species that showed signs of changes in their population density. $P$-values provided by the models were adjusted for multiple comparisons using the Benjamini-Hochberg correction. Significant differences are highlighted in bold. Positive estimate values indicate an increase in population density over the study period, while negative values indicate a decrease in population density.

\begin{tabular}{rlccccc}
\hline \hline No. & Species $^{1}$ & Estimate & Standard error & t value & $p$-value & Benjamini-Hochberg-adjusted $p$-value \\
\hline 1 & Willow Ptarmigan & $\mathbf{- 0 . 0 4 8}$ & $\mathbf{0 . 0 1 9}$ & $\mathbf{- 2 . 5 1 4}$ & $\mathbf{0 . 0 1 5}$ & $\mathbf{0 . 0 3}$ \\
2 & Eurasian Teal & 0.011 & 0.042 & 0.267 & 0.793 & 0.793 \\
3 & Greater Scaup & $\mathbf{0 . 0 8 9}$ & $\mathbf{0 . 0 3 3}$ & $\mathbf{2 . 6 7 7}$ & $\mathbf{0 . 0 1 3}$ & 0.559 \\
4 & European Golden Plover & 0.024 & 0.040 & 0.594 & 0.55 & $\mathbf{0 . 0 0 9}$ \\
5 & Black-bellied Plover & $\mathbf{- 0 . 1 5 1}$ & $\mathbf{0 . 0 4 6}$ & $-\mathbf{3 . 3 0}$ & $\mathbf{0 . 0 0 2}$ & 0.081 \\
6 & Ruff & -0.097 & 0.046 & -2.099 & 0.047 & 0.082 \\
7 & Dunlin & $\mathbf{- 0 . 0 4 4}$ & $\mathbf{0 . 0 1 5}$ & $\mathbf{- 2 . 8 5 5}$ & $\mathbf{0 . 0 0 6}$ & 0.055 \\
8 & Little Stint & -0.097 & 0.048 & -2.024 & 0.810 & $\mathbf{0 . 0 0 9}$ \\
9 & Common Snipe & 0.050 & 0.062 & $\mathbf{- 3 . 2 1 6}$ & $\mathbf{0 . 0 0 2}$ & 0.428 \\
10 & Parasitic Jaeger & $\mathbf{- 0 . 0 7 9}$ & $\mathbf{0 . 0 2 4}$ & 1.006 & 0.321 & $\mathbf{0 . 0 0 5}$ \\
11 & Meadow Pipit & 0.027 & 0.027 & $\mathbf{- 3 . 7 8 7}$ & $\mathbf{0 . 0 0 0 4}$ & \\
12 & Lapland Longspur & $\mathbf{0 . 0 4 1}$ & $\mathbf{0 . 0 1 1}$ & & \\
\hline \hline
\end{tabular}

${ }^{1}$ Barnacle Goose was not included in the table, since the method used to calculate the population density was inappropriate for this species due to its inhomogeneous distribution as a colonial nesting species.

Plover (Pluvialis squatarola), Dunlin, Parasitic Jaeger (Stercorarius parasiticus), and Lapland Longspur. The population density of the remaining species did not change significantly over the study period.

The density of Willow Ptarmigan was extremely high on Kolguev at the beginning of our study, but the population numbers significantly declined over the 10 -year period (Table 2, Fig. 2). The average densities were 98.72 and 97.59 ind. $/ \mathrm{km}^{2}$ in 2006 and 2007, respectively. In 2008, the population density dramatically declined to an average of 25.98 ind. $/ \mathrm{km}^{2}$. The population density of the species remained low in 2011 (34.66 ind. $\left./ \mathrm{km}^{2}\right), 2012$ (4.76 ind. $\left./ \mathrm{km}^{2}\right)$, 


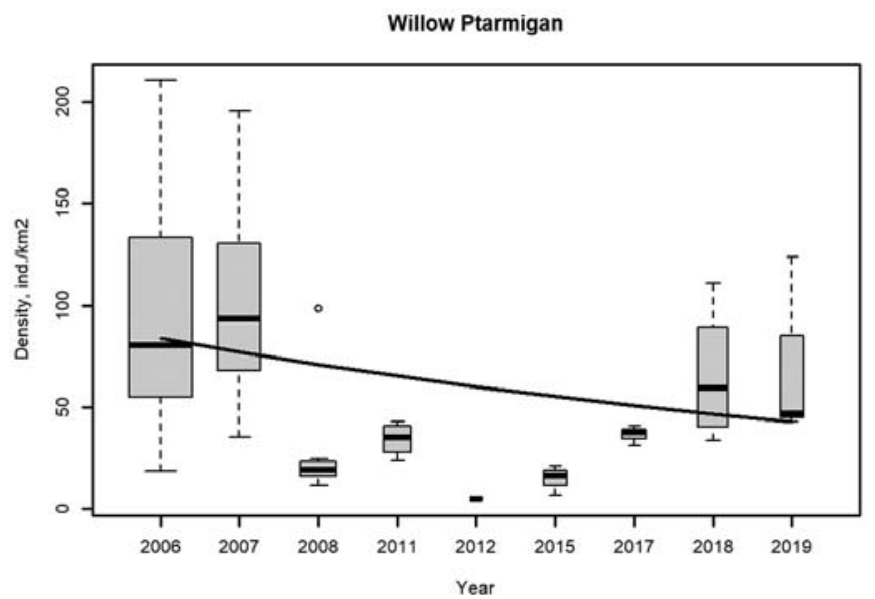

FIG. 2. Dynamics of the population density of Willow Ptarmigan in 2006-19 according to route censuses. Plots show the median (horizontal line in the box), lower and upper quartiles (horizontal box boundaries), and minimum and maximum values (whiskers); dots indicate outliers. The black line represents the model-predicted changes in population density over the years.

2015 (12.37 ind. $/ \mathrm{km}^{2}$ ), and 2017 (37.72 ind./ $\left./ \mathrm{km}^{2}\right)$. Since 2017, the density of the species started increasing and reached average values of 63.82 and $57.9 \mathrm{ind} . / \mathrm{km}^{2}$ in 2018 and 2019, respectively. Thus, year-to-year comparisons of population density showed cyclical changes rather than population decline (Table 3).

The population density of Greater Scaup increased during the study (Table 2, Fig. 3), however, the differences between years were not significant. The minimum density of $0.48 \mathrm{ind} . / \mathrm{km}^{2}$ was observed in 2006 , and the maximum density of $8.82 \mathrm{ind} . / \mathrm{km}^{2}$ was recorded in 2018. In 2019, the density of Greater Scaup on the total observed area of 128.4 $\mathrm{km}^{2}$ was 2.2 ind. $/ \mathrm{km}^{2}$.

The population density of Black-bellied Plover significantly declined over the study period (Table 2, Fig. 4), however, the differences between years were not significant. The density ranged from $0.12 \mathrm{ind} . / \mathrm{km}^{2}$ in 2019 to 7.37 ind. $/ \mathrm{km}^{2}$ in 2007. During the complete counts of territorial pairs in 2019, the breeding density of Black-bellied Plover was 0.1 pairs $/ \mathrm{km}^{2}$. In 2018, the breeding density was 0.15 pairs $/ \mathrm{km}^{2}$ for a smaller area.

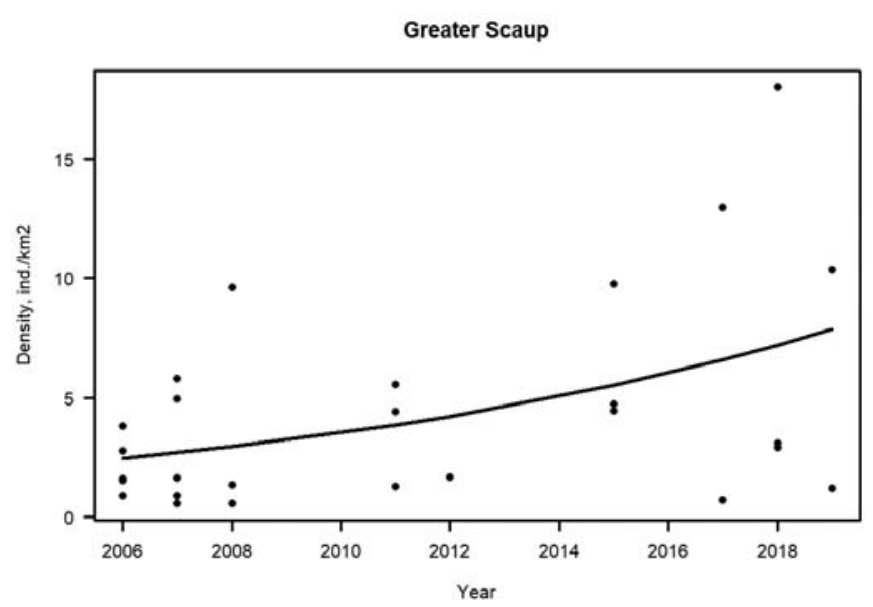

FIG. 3. Dynamics of the population density of Greater Scaup in 2006-19 according to route censuses. The black line represents the model-predicted changes in population density over the years.

The population density of Dunlin significantly decreased over the study period (Table 2, Fig. 5), however, the differences between years were not significant. The minimum density of 21.93 ind. $/ \mathrm{km}^{2}$ was observed in 2017 , while the maximum density of 48.02 ind. $/ \mathrm{km}^{2}$ was recorded in 2018.

The population density of Parasitic Jaeger significantly declined over the study period (Table 2, Fig. 6), however, the differences between years were not significant. The density of Parasitic Jaeger varied from 0.43 ind. $/ \mathrm{km}^{2}$ in 2017 to 3.29 ind. $/ \mathrm{km}^{2}$ in 2007. According to the survey data in 2019, the breeding density of Parasitic Jaeger was 0.14 pairs $/ \mathrm{km}^{2}$.

The population density of Lapland Longspur decreased over the study period (Table 2, Fig. 7). The average densities varied between 79.22 and 98.74 ind./ $/ \mathrm{km}^{2}$ in $2006-08$. The population density declined to $32.15 \mathrm{ind} . / \mathrm{km}^{2}$ in 2017 and remained low in 2018 with an average density of 58.08 ind. $/ \mathrm{km}^{2}$. In 2019 , the population density of Lapland Longspur reached the level of former years at 73.23 ind. $/ \mathrm{km}^{2}$ (Table 4).

TABLE 3. Results of the post-hoc tests of differences between years for Willow Ptarmigan. $P$-values were adjusted for multiple comparisons using Duncan's multiple range test. Only significant results are shown, the rest of the comparisons were not significant.

\begin{tabular}{|c|c|c|c|c|c|}
\hline Years compared & Difference of means & SE & Confidence interval & t-value & Adjusted $p$-value \\
\hline $2006-08$ & 4.410 & 0.985 & $2.175,6.646$ & 4.478 & 0.0001 \\
\hline $2006-11$ & 3.642 & 1.234 & $0.889,6.395$ & 2.952 & 0.0094 \\
\hline $2006-12$ & 7.283 & 2.321 & $1.888,12.677$ & 3.138 & 0.0078 \\
\hline $2006-15$ & 5.729 & 1.397 & $2.516,8.941$ & 4.101 & 0.0005 \\
\hline $2006-17$ & 3.441 & 1.397 & $0.393,6.489$ & 2.463 & 0.0269 \\
\hline $2007-08$ & 4.591 & 1.119 & $2.019,7.164$ & 4.104 & 0.0005 \\
\hline $2007-11$ & 3.823 & 1.343 & $0.776,6.871$ & 2.847 & 0.0137 \\
\hline $2007-12$ & 7.463 & 2.381 & $1.881,13.046$ & 3.135 & 0.0084 \\
\hline $2007-15$ & 5.910 & 1.494 & $2.436,9.383$ & 3.955 & 0.0008 \\
\hline $2007-17$ & 3.622 & 1.494 & $0.288,6.956$ & 2.424 & 0.0331 \\
\hline $2008-18$ & -2.906 & 1.329 & $-5.806,-0.006$ & -2.186 & 0.0495 \\
\hline $2012-18$ & -5.778 & 2.486 & $-11.421,-0.135$ & -2.324 & 0.0447 \\
\hline $2015-18$ & -4.224 & 1.658 & $-7.923,-0.525$ & -2.548 & 0.0251 \\
\hline $2015-19$ & -4.432 & 1.853 & $-8.638,-0.226$ & -2.391 & 0.0388 \\
\hline
\end{tabular}




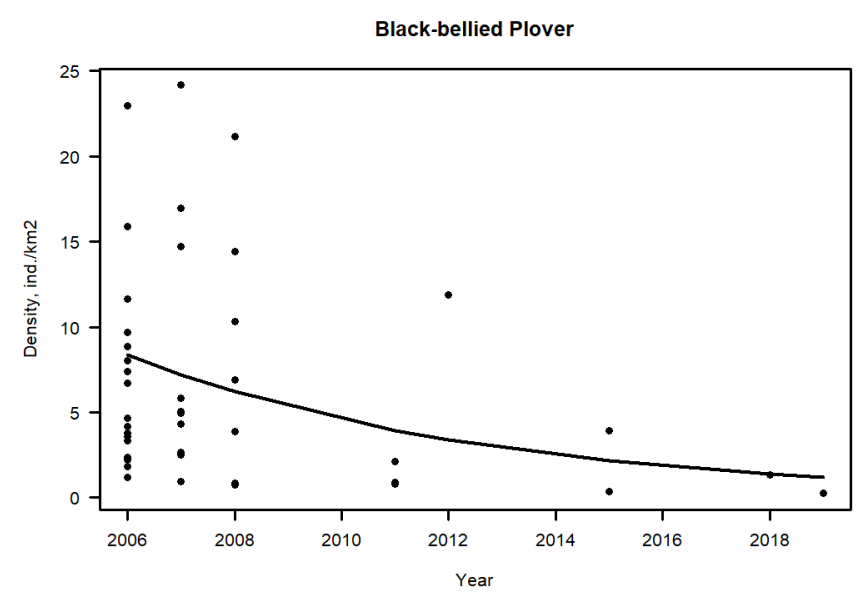

FIG. 4. Dynamics of the population density of Black-bellied Plover in 2006-19 according to route censuses. The black line represents the modelpredicted changes in population density over the years.

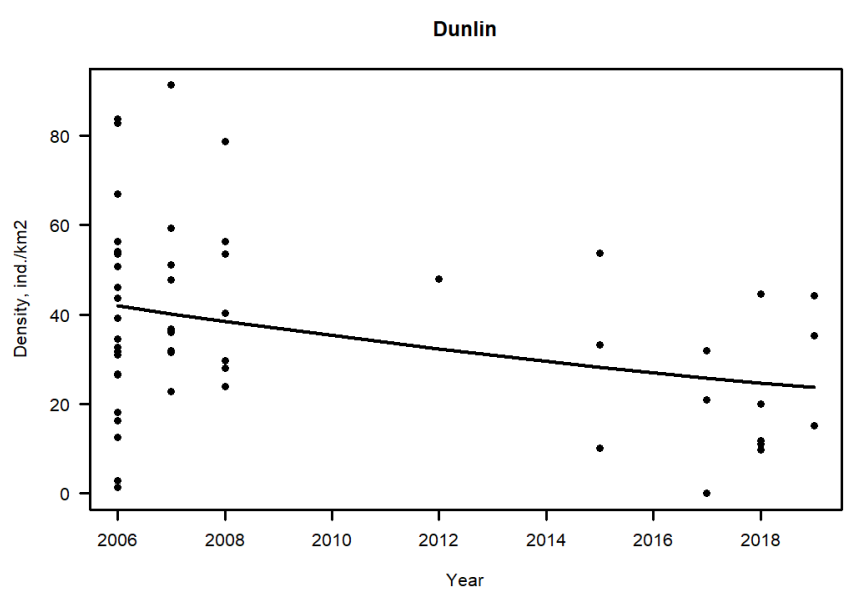

FIG. 5. Dynamics of the population density of Dunlin in 2006-19 according to route censuses. The black line represents the model-predicted changes in population density over the years.

TABLE 4. Results of the post-hoc tests of differences between years for Lapland Longspur. $P$-values were adjusted for multiple comparisons using Duncan's multiple range test. Only significant results are shown, the rest of the comparisons were not significant.

\begin{tabular}{|c|c|c|c|c|c|}
\hline Years compared & Difference of means & SE & Confidence interval & t-value & Adjusted $p$-value \\
\hline $2006-17$ & 4.037 & 1.067 & $1.648,6.426$ & 3.782 & 0.0010 \\
\hline $2006-18$ & 2.268 & 0.864 & $0.378,4.158$ & 2.626 & 0.0189 \\
\hline $2007-17$ & 4.368 & 1.131 & $1.761,6.976$ & 3.862 & 0.0011 \\
\hline $2007-18$ & 2.599 & 0.941 & $0.457,4.741$ & 2.762 & 0.0173 \\
\hline $2008-17$ & 4.437 & 1.186 & $1.674,7.199$ & 3.742 & 0.0017 \\
\hline $2008-18$ & 2.668 & 1.006 & $0.348,4.987$ & 2.651 & 0.0241 \\
\hline $2015-17$ & 4.065 & 1.403 & $0.872,7.257$ & 2.897 & 0.0126 \\
\hline $2017-19$ & -3.537 & 1.403 & $-6.608,-0.46$ & -2.521 & 0.0242 \\
\hline
\end{tabular}

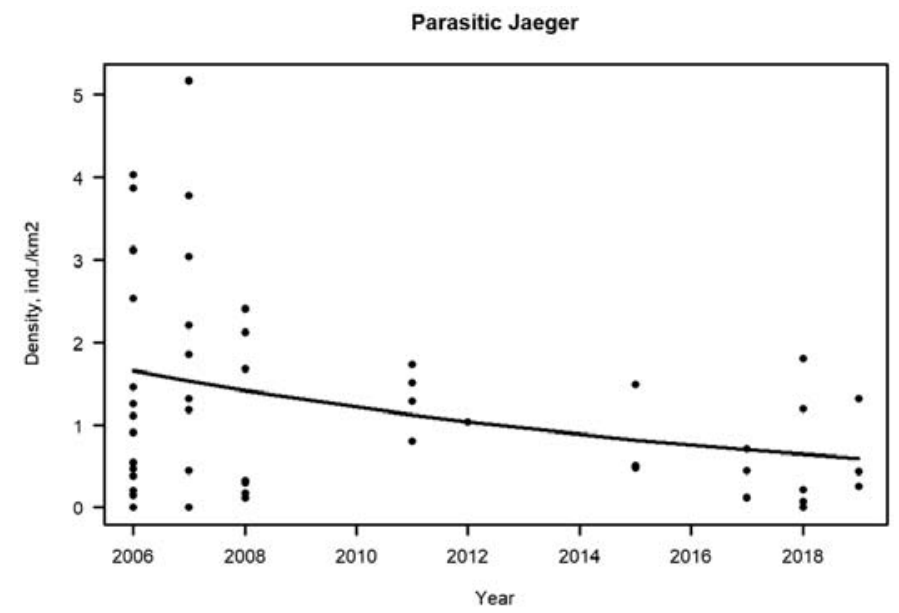

FIG. 6. Dynamics of the population density of Parasitic Jaeger in 2006-19 according to route censuses. The black line represents the model-predicted changes in population density over the years.

The population density of Greater White-fronted Goose did not change during our study. Interannual comparisons of breeding densities of the species based on the nest counts on the permanent plots showed a significant variation in breeding density between different years $(\beta=1.244 \pm 0.597$ $(\mathrm{SE}), \mathrm{t}=2.085, p=0.044)$; however, no directional trend was observed (Fig. 8). The only significant difference in the

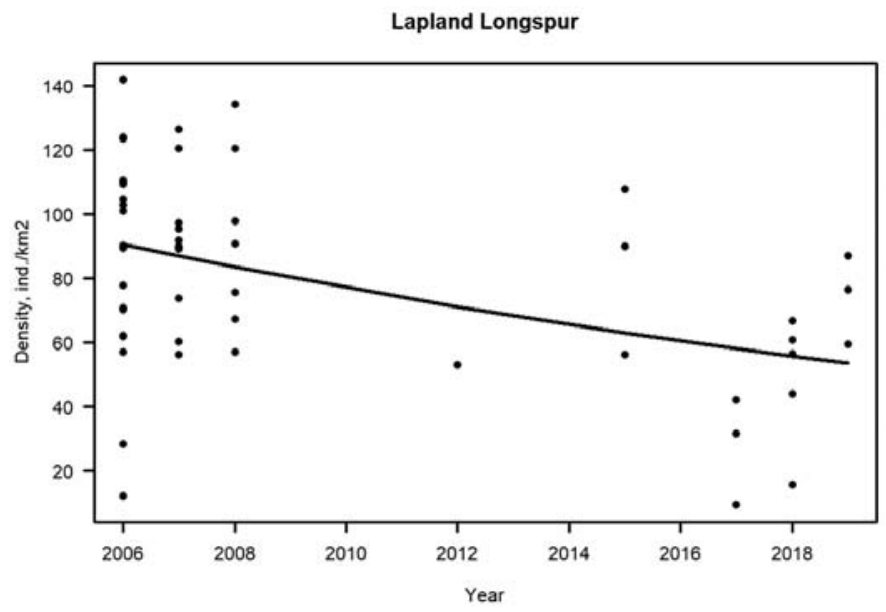

FIG. 7. Dynamics of the population density of Lapland Longspur in 2006-19 according to route censuses. The black line represents the model-predicted changes in population density over the years.

breeding density of Greater White-fronted Goose was in 2018 compared to $2007(\beta=22.111 \pm 9.763(\mathrm{SE}), \mathrm{t}=2.265$, $p=0.032$ ).

Similarly, the population density of Tundra Bean Goose as calculated by the route censuses did not change during the study period. The breeding density based on the nest counts on the permanent plots, however, varied 
Greater White-fronted Goose

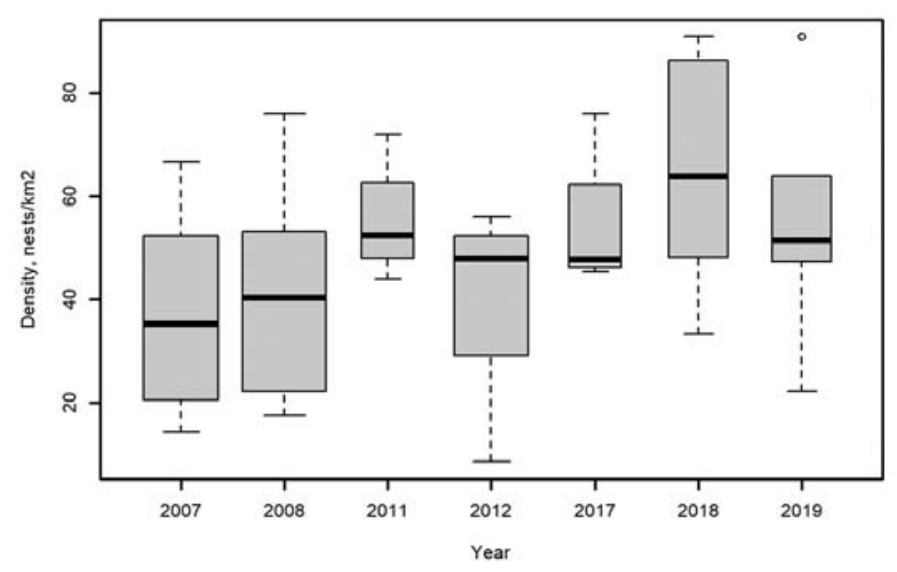

FIG. 8. Dynamics of the breeding density of Greater White-fronted Goose in 2007-19 according to the complete nest counts on the permanent plots. Plots show the median (horizontal line in the box), lower and upper quartiles (horizontal box boundaries), and minimum and maximum values (whiskers); dots indicate outliers.

significantly ( $\beta=0.547 \pm 0.188(\mathrm{SE}), \mathrm{t}=2.908, p=0.008)$, showing a higher density in the last two years (Fig. 9). The nesting density of Tundra Bean Goose was higher in 2018 compared to $2008(\beta=6.603 \pm 3.032(\mathrm{SE}), \mathrm{t}=2.178$, $p=0.046)$ and $2012(\beta=7.752 \pm 3.083(\mathrm{SE}), \mathrm{t}=2.515$, $p=0.023)$, and in 2019 compared to $2008(\beta=8.202 \pm 3.032$ (SE), $\mathrm{t}=2.705, p=0.016)$ and $2012(\beta=9.352 \pm 3.083(\mathrm{SE})$, $\mathrm{t}=3.034, p=0.008)$. The nesting density did not differ in other years.

The route census method is not accurate for birds of prey occurring in relatively small densities because the average route length was $8.3 \mathrm{~km}$. To obtain information on the distribution of raptor species, we carried out complete counts of territorial pairs of both species over the area of $150-350 \mathrm{~km}^{2}$. The core area was the same in most years. The density of territorial pairs of Rough-legged Hawk increased significantly during the study $(\beta=0.327 \pm 0.075$ (SE), $\mathrm{t}=4.334, p=0.005$; Fig. 10) from 1.4 pairs $/ 100 \mathrm{~km}^{2}$ in 2008 to 6.3 pairs $/ 100 \mathrm{~km}^{2}$ in 2018 . The density of territorial pairs of Peregrine Falcon (Falco peregrinus) did not change over our study $(\beta=-0.028 \pm 0.026(\mathrm{SE}), \mathrm{t}=-1.072$, $p=0.325$; Fig. 10). The density of territorial pairs varied from 1.5 pairs $/ 100 \mathrm{~km}^{2}$ in 2017 to 2.3 pairs $/ 100 \mathrm{~km}^{2}$ in 2008 and 2019.

\section{DISCUSSION}

\section{General Trends of Avifauna}

Our comprehensive study of the avifauna of Kolguev Island resulted in complete data on the bird species inhabiting the island, their abundance and population dynamics over the past 15 years. The modern list of bird species recorded on the island includes 111 species (Supplement Table S1). Fifty-eight species are nesting on

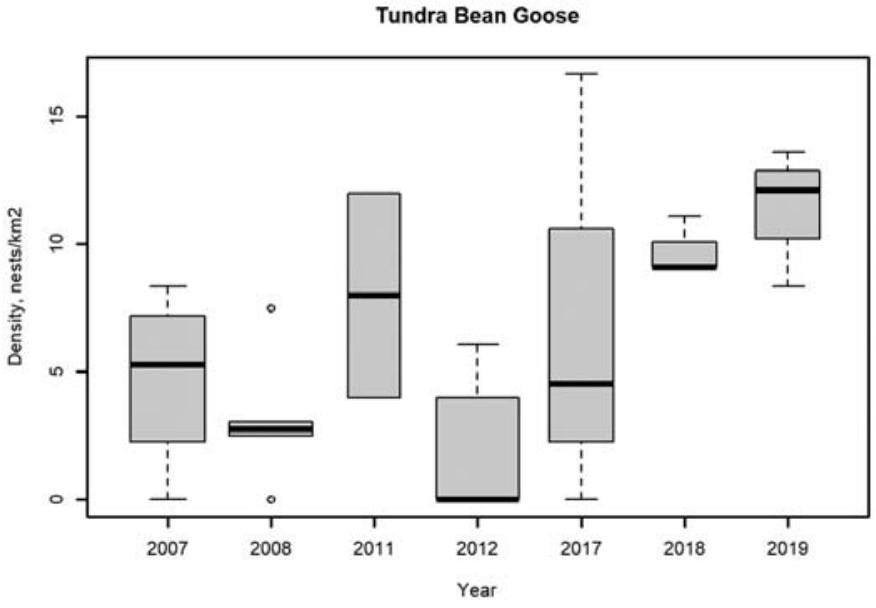

FIG. 9. Dynamics of the breeding density of Tundra Bean Goose in 2007-19 according to the complete nest counts on the permanent plots. Plots show the median (horizontal line in the box), lower and upper quartiles (horizontal box boundaries), and minimum and maximum values (whiskers); dots indicate outliers.

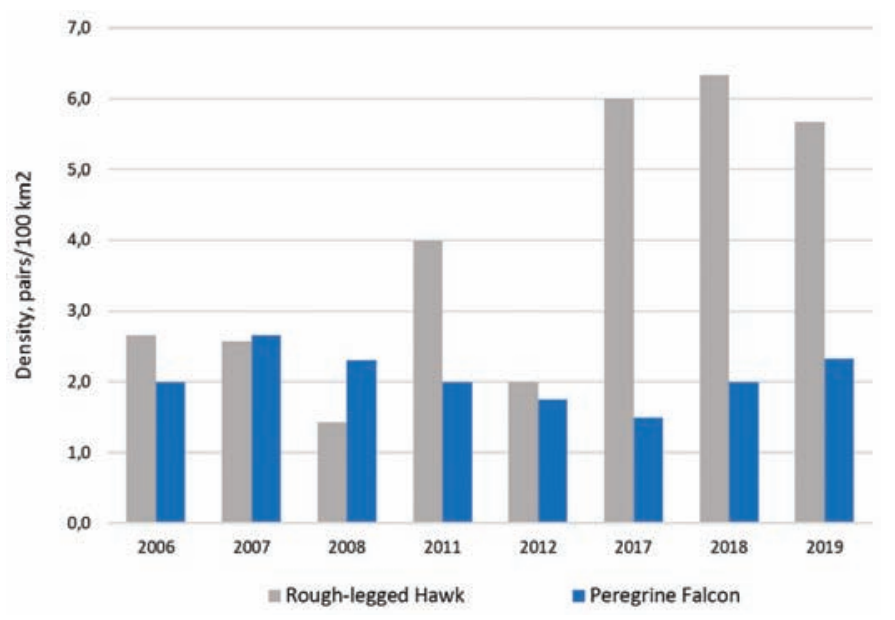

FIG. 10. Dynamics of the breeding density of Rough-legged Hawk (grey) and Peregrine Falcon (blue) in 2006-19 according to the complete nest counts within the study area of the central part of the island.

the island, among which 35 can be classified as common species that regularly breed throughout the island (Kondratyev et al., 2019).

In the first quarter of the 20th century, the list of bird species on Kolguev Island (Trevor-Battye, 1895; Zhitkov and Buturlin, 1901; Buturlin, 1903; Tolmachev, 1927) included 59 species (Pleske, 1928; Table S1). At the core of the avifauna composition (69\%) were Arctic (often circumpolar) species, including typical tundra species and species of open spaces. The proportion of widespread and Siberian species was $12 \%$ each, while European, Mediterranean, Mongolian, and Chinese species each accounted for $2 \%$ of the avifauna (classification according to Shtegman, 1938).

During the 125-year history of ornithological research on Kolguev (1894-2019), the ratio of species inhabiting the island has changed significantly. The proportion of Arctic species has decreased from $69 \%$ to $48 \%$, while 
other species complexes have increased in proportion: widespread species from $12 \%$ to $22 \%$, Siberian species from $12 \%$ to $19 \%$, and European species from $2 \%$ to $7 \%$. The remaining $4 \%$ of species are Chinese, Mediterranean, Tibetan, and Mongolian at $1 \%$ each. Over the past 25 years, the overall species composition has not changed much, but there are trends in breeding species. Among breeding species, the proportion of Arctic species has decreased from $66 \%$ to $58 \%$, while the proportion of widespread and Siberian species increased (from $14 \%$ to $17 \%$ and from $11 \%$ to $16 \%$, respectively). The proportion of other groups did not change, with European species at 5\%, Mediterranean species at $2 \%$, and Chinese species also at $2 \%$. The trend towards an increase in the proportion of Siberian species is observed not only for birds but also for other groups of animals (Makarova et al., 2019). The significant contribution of Siberian species to the fauna of various groups of animals in the Nenets Autonomous District (up to $31 \%$ ) confirms the conclusion drawn 140 years ago by Seebohm (1880) based on ornithological material, that from a zoological point of view, the studied region can be characterized as "Siberia in Europe." The trend towards an increase in the proportion of widespread and Siberian species together with a decrease in the proportion of Arctic species most likely will continue in the region in the future, especially regarding Siberian species.

Not only the species composition but also the abundance of some species changed significantly during the 20th century. For example, Brant (Branta bernicla) was a numerous molting species on Kolguev at the end of the 19th century (Trevor-Battye, 1895) but had almost completely disappeared by the end of the 20th century (Morozov and Syroechkovsky, 2004). The ratio of Tundra Bean Goose and Greater White-fronted Goose also changed: Tundra Bean Goose noticeably predominated in the late 19th-20th centuries (Trevor-Battye, 1895; Zhitkov and Buturlin, 1901; Tolmachev, 1927), and Greater White-fronted Goose predominated at the end of the 20th century (Morozov and Syroechkovsky, 2004). Barnacle Goose began to nest on the island in the 1980s (Ponomareva, 1990; Gavrilo, 1991) and became one of the most numerous breeding species by the mid-1990s (Morozov and Syroechkovsky, 2004; Anufriev, 2006; Kondratyev et al., 2013).

There was also an expansion of Meadow Pipit on the island in the 20th century. In the late 19th to early 20th century, it was observed only once (Trevor-Battye, 1895), but in 1994-95 it was a common and locally abundant species (Morozov and Syroechkovsky, 2004). The expansion of Meadow Pipit to the tundra zone of Europe and Western Siberia occurred intensively during the 20th century, as seen in the comparison of the breeding ranges from different years (Gladkov, 1954; Ryabitsev, 2001).

\section{Current Population Dynamics}

During our research, carried out from 2006 to 2019, we managed to collect more detailed information not only on the status of species, but also on their numbers. Based on the route censuses data, we were able to calculate the population density for 33 species (Table 1). Significant changes in population dynamics were observed for Willow Ptarmigan, Greater Scaup, Black-bellied Plover, Dunlin, Parasitic Jaeger, and Lapland Longspur. While the dynamics of some species may be driven by interannual variation, trends in the population density for some of them may reflect global changes in the abundance of the species.

\section{Willow Ptarmigan}

The population density of Willow Ptarmigan changed during our study. There was a decline in 2008 and depression for nine years $(2008-17)$. In 2017, the population started growing and reached the next maximum in 2018 i.e., 12 years after the previous peak in 2006-07. Population cycles are well known for Willow Ptarmigan (Myrberget, 1974; Moss and Watson, 2001). Cycle periods varying from $3-4,6$, and 10 years have been documented in different populations of Willow Ptarmigan (Watson and Moss, 1979). In the eastern European Arctic, the cycles of Willow Ptarmigan had a period of 3-4 years (Mineev and Mineev, 2017), similar to Scandinavian Willow Ptarmigan (Myrberget, 1974; Moss and Watson, 2001). However, since the 1990s, the abundance of Willow Ptarmigan in the eastern European Arctic has declined, and the 3-4-year cycles have been disrupted (Anufriev, 2012b; Mineev and Mineev, 2017). This decline may be related to the crash of lemming cycles, since the cycles of Willow Ptarmigan have been shown to be correlated with the cycles of rodents (Myrberget, 1974; Hörnfeldt, 1978; Moss and Watson, 2001). Since then, the population dynamics on the mainland of the eastern European Arctic have shown cycles over a period of 10 years instead of 3-4 years (Anufriev, 2012b; Mineev and Mineev, 2017). Ten-year cycles of Willow Ptarmigan are also widespread in Siberia (Andreev, 1988) and North America (Bergerud, 1970). Even though there are no rodents on Kolguev, the population cycles of Willow Ptarmigan still occur there and are in general synchronous with the dynamics on the mainland (Malozemelskaya and Bolshezemelskaya tundras). In the Bolshezemelskya tundra, the peak of Willow Ptarmigan abundance was in 2007 and the decline in 2008-09 (Anufriev, 2010, 2012b; Mineev and Mineev, 2017). The abundance in the Bolshezemelskya tundra was low from 2008 until 2014 (there were no subsequent data), and the same pattern was observed in the Malozemelskaya tundra (Mineev and Mineev, 2017). Since birds from Kolguev are migratory and can spend the winter in the same area as birds from the Malozemelskaya tundra, the same factors may determine their population cycles and result in synchronization of their cycles. In general, the population density of Willow Ptarmigan on Kolguev was considerably higher during the study than on the adjacent mainland, even during the low-density period (Mineev and Mineev, 2017), which may relate to the stable predator pressure on the island. 


\section{Greater Scaup}

Among ducks, an increase in the number of Greater Scaup was observed (Table 2). It was a scarce breeding species in 1994-95, but has now become a common duck species on the island (Table S1). According to an aerial survey in 1994, the density of Greater Scaup in the inland tundra of Kolguev Island was $0.1 \mathrm{ind} . / \mathrm{km}^{2}$ (Morozov and Syroechkovsky, 2004), while in 2019 the species density in central Kolguev was 2.2 ind. $/ \mathrm{km}^{2}$. These differences indicate an increase in the numbers of Greater Scaup. The density of the species in the inner part of the island was similar to reported densities in the inland areas on the mainland, where it varied from 0.3 to 1.5 ind. $/ \mathrm{km}^{2}$ in the Malozemelskaya tundra (Mineev and Mineev, 2009) and from 0.2 to 3.4 ind. $/ \mathrm{km}^{2}$ in the Bolshezemelskaya tundra (Mineev and Mineev, 2012). A trend towards an increase in the wintering population of Greater Scaup was observed in the eastern parts of the Baltic Sea: in Poland in 2002-18 (Marchowski et al., 2018) and in Germany in 2004-16 (Gerlach et al., 2019). A similar trend was found in Sweden, where the number of wintering Greater Scaup increased between 1971 and 2015 (Nilsson and Haas, 2016). However, the population of Greater Scaup wintering in northern and western Europe declined at an annual rate of 3.57\%/year between the late 1980s and 2012 (Nagy et al., 2014). In the Netherlands, Hornman et al. (2012) recorded decreases at the most important wintering sites since 1980-81. All these studies confirm that Greater Scaup is shifting its wintering range northwards and eastwards, closer to its breeding areas (Marchowski et al., 2017; see also Fox et al., 2019). We can speculate that the same pattern may occur in the breeding area, and the species will spread to more northern areas.

\section{Black-bellied Plover}

Among waders, the most pronounced changes were observed in Black-bellied Plover and Dunlin. The population density of Black-bellied Plover significantly decreased during our study. This species was reported as abundant by all researchers who visited the island during the late 19th-20th centuries (Trevor-Battye, 1895; Pearson, 1896; Zhitkov and Buturlin, 1901; Tolmachev, 1927; Glazov, 1998). Morozov and Syroechkovsky (2004) reported that the breeding density in the Peschanka Delta was 46 pairs/10 $\mathrm{km}^{2}$ in 1995. However, such a high density of Black-bellied Plover was observed only within the $5 \mathrm{~km}$ coastal tundra zone, whereas in the interior parts of the island this species was rare. Despite this, they estimated the total Kolguev breeding population at 5000 pairs, which is almost half of the estimated breeding population of the European Arctic (2500-12,500 pairs; Lappo et al., 2012). Kolguev is the westernmost of the main breeding sites of Blackbellied Plover in the Western Palearctic and has the highest nesting density in the entire Western Palearctic range of this species, while the majority of the Palearctic population breeds in Siberia (Kruckenberg et al., 2012).
The average population density of Black-bellied Plover obtained during our route censuses in 2006-08 was 6 ind./ $\mathrm{km}^{2}$, which corresponds to the breeding densities reported for the same years: $1-2$ pairs $/ \mathrm{km}^{2}$ in central Kolguev, more than 2 pairs $/ \mathrm{km}^{2}$ on the western coast, and 3.6 pairs $/ \mathrm{km}^{2}$ in the eastern coastal tundra (Kruckenberg et al., 2012). This density in the eastern coastal tundra was less than reported for the same area in 1995 (4.58 pairs $/ \mathrm{km}^{2}$; Morozov and Syroechkovsky, 2004). Although the 1995 data were obtained for only one year, these differences suggest that the breeding density of Black-bellied Plover decreased from 1995 to $2006-08$.

According to our data, the population density of Blackbellied Plover decreased during 2015-19 to 0.6 ind./ $\mathrm{km}^{2}$, and the breeding density was $0.1-0.15$ pairs $/ \mathrm{km}^{2}$ in 2018-19 in the central part of the island, which is a much lower breeding density compared to that for central Kolguev in 2006-08 (1-2 pairs $/ \mathrm{km}^{2}$; Kruckenberg et al., 2012). These data indicate the further decline in the Blackbellied Plover population on Kolguev Island.

This decline is consistent with a negative trend in the number of Black-bellied Plovers on wintering grounds. Birds nesting in the European Arctic migrate through Western Europe to East Atlantic wintering regions (Exo et al., 2019). In the European part of the wintering range, the population increased from 1979 to the mid-1990s with stabilization or a slow decline afterwards; in African wintering areas, the species shows a sustained decline at an annual rate of 1\% (van Roomen et al., 2015). In the 1990s, the overall wintering population size was estimated to be 250,000 birds (Stroud et al., 2004). In 2015, a population size of 200,000 was estimated, reflecting the population decrease between the mid-1990s and 2014 by c. $20 \%$ (van Roomen et al., 2015). In the Wadden Sea, which almost $60 \%$ of the total flyway population of Black-bellied Plover uses outside the breeding season, the numbers of Blackbellied Plover increased from the 1980s and showed a short peak during the mid-1990s; afterwards, a short decrease was followed by a stable period (van Roomen et al., 2017; Kleefstra et al., 2019). Long-term trends (1987-88 to 2016-17) showed an increase in the Netherlands and Denmark and a moderate decrease in Niedersachsen/ Hamburg and Schleswig-Holstein; however, shortterm trends (2007-08 to 2016-17) were stable in the Netherlands and Denmark and showed a moderate decrease in Niedersachsen/Hamburg and Schleswig-Holstein (Blew et al., 2016; Kleefstra et al., 2019). The total flyway population experienced a short-term decline from 2006 to 2015 (Wetlands International, 2020).

\section{Dunlin}

Dunlin, the most abundant wader species on Kolguev, also showed a negative trend in its population numbers. In 1995 , the nesting density of the species was 55 pairs $/ \mathrm{km}^{2}$, and the total numbers were estimated at 150,000-175,000 nesting pairs (Morozov and Syroechkovsky, 2004). 
In 2006-08, Kruckenberg et al. (2012) estimated the overall average breeding density at $5-6$ pairs $/ \mathrm{km}^{2}$, peaking in the boggy areas around the Peschanka Delta at $10-12$ pairs $/ \mathrm{km}^{2}$. According to our route censuses, the population density of Dunlin in the same years was 36 ind./ $\mathrm{km}^{2}$. During $2015-19$, a slight decline to 26 ind./ $\mathrm{km}^{2}$ was observed in the population density, while the species remained the most abundant wader species on the island. The population density of Dunlin is much higher on Kolguev than that reported for the neighboring Arctic regions; the population density was $0.4-11.1$ ind. $/ \mathrm{km}^{2}$ in the Malozemelskaya tundra (Mineev and Mineev, 2009) and $0.47-9.38$ ind. $/ \mathrm{km}^{2}$ in the Bolshezemelskaya tundra (Mineev and Mineev, 2012).

The overall long-term (1987-88 to 2016-17) and short-term (2007-08 to 2016-17) trends show moderate decreases in the Wadden Sea, where large numbers and most likely large proportions of about $70 \%$ of the East Atlantic flyway populations are present during the annual cycle. The decrease is occurring in the northern part of the Wadden Sea (Denmark, Schleswig-Holstein), while numbers are either stable (Niedersachsen) or increasing (the Netherlands) in the southern part (Blew et al., 2016; van Roomen et al., 2017; Kleefstra et al., 2019). The short-term trend since 2003 shows a slight average decline of $1 \%$ per year in the Wadden Sea. This decline is also apparent for the breeding populations (van Roomen et al., 2015), which suggests the same trends may occur in the Arctic breeding grounds.

\section{Ruddy Turnstone}

While we were able to trace the dynamics in the populations of some species, there are also trends that were not reflected in the current study. For example, noticeable differences in abundance were found for Ruddy Turnstone between 1994 and 2006. In 1994, Morozov and Syroechkovskiy (2004) found that Ruddy Turnstones bred at densities of up to 29 nests $/ \mathrm{km}^{2}$ in the coastal tundra zone, and that over $60 \%$ of nests were in upland habitats adjacent to the Peschanka River valley. Our observations in 2006-08 indicated that the species became a very rare breeder on Kolguev, with nests located mainly on the coastline in the southern and eastern parts of the island. In $2006-08$, the estimated overall density did not exceed $0.01-0.1$ pairs $/ \mathrm{km}^{2}$, indicating a dramatic five- to eightfold decline in the population from 1994 to 2006-08 (Kruckenberg et al., 2012; Kondratyev et al., 2019).

\section{Parasitic Jaeger}

We found a decrease in the population density of Parasitic Jaeger during our study. In 2019, the breeding density was 0.14 pairs $/ \mathrm{km}^{2}$ in the central part of Kolguev. In 1995, the breeding density of Parasitic Jaeger was five pairs $/ 10 \mathrm{~km}^{2}$ in the Peschanka Delta (Morozov and Syroechkovsky, 2004), which corresponds to the population density in 2006-08 and thus indicates no population trend in this species between 1995 and 2006-08. Population decline in recent years may be a consequence of the depression in the numbers of Willow Ptarmigan, which can be a considerable food resource for Parasitic Jaeger in the absence of rodents. Davis et al. (2005) showed that food availability has a significant and sustained impact on the population dynamics of Parasitic Jaeger.

Population densities of Parasitic Jaeger in the neighboring areas on the mainland did not differ from the densities observed on Kolguev. Densities varied from 0.1 to 2.29 ind. $/ \mathrm{km}^{2}$ (Mineev and Mineev, 2009) in the Malozemelskaya tundra and from 0.02 to 1 ind. $/ \mathrm{km}^{2}$ in the Bolshezemelskaya tundra (Mineev and Mineev, 2012).

\section{Lapland Longspur}

Among the passerines, there was a decline in the population density of the most abundant species on the island, the Lapland Longspur. The population density decreased from 89 ind. $/ \mathrm{km}^{2}$ in $2006-08$ to 64 ind. $/ \mathrm{km}^{2}$ in 2015-19, but it remained the most abundant species on the island. In 1995, the breeding density of Lapland Longspur was 29 pairs $/ \mathrm{km}^{2}$ (Morozov and Syroechkovsky, 2004). The population density of Lapland Longspur was considerably less on the mainland than on Kolguev, varying from 0.8 to 24.6 ind. $/ \mathrm{km}^{2}$ in the Malozemelskaya tundra (Mineev and Mineev, 2009) and from $0.5-26.7$ ind. $/ \mathrm{km}^{2}$ in the Bolshezemelskaya tundra (Mineev and Mineev, 2012). A downward trend in Lapland Longspur was also observed in Norway (Byrkjedal and Kålås, 2012). However, from our data, we cannot argue that our trend reflects a population decline and not the interannual fluctuations known for this species (Byrkjedal and Kålås, 2012; Mineev and Mineev, 2012).

\section{Breeding Populations of Geese}

The breeding density of Greater White-fronted Goose is extremely high on Kolguev, reaching 91 nests $/ \mathrm{km}^{2}$ in some habitats in some years. The breeding density of Tundra Bean Goose reached a value of 17 nests $/ \mathrm{km}^{2}$ in certain habitats in some years. The densities of both species undergo interannual fluctuations related to weather conditions. Thus, 2018 and 2019 were very successful, resulting in high numbers of nesting geese, while in 2017 the late spring led to low numbers of nesting geese.

One of the most notable events of recent years was the ubiquitous rapid growth in the numbers of Barnacle Goose throughout the island, including the central areas (Kondratyev et al., 2012, 2013). In the course of our route censuses, we were not able to detect this growth because Barnacle Geese breed in colonies, while our counting routes mainly passed outside the colonies. In 2006-08, colonies of Barnacle Goose in the central part of the island were associated with the nests of their main patron species, the Peregrine Falcon. Such colonies numbering from 20 to 100 
pairs were marked both along riverbanks and in watershed cirques (semicircular or crescent-shaped basins with steep sides and gently sloping floors formed in mountain regions by the erosive action of glaciers). For the first time, single nests were located on the margins of the lakes with swampy basins and along steep banks in the creek valleys. In 2011-12, the first relatively large colonies of this species (from 40 to 80 pairs) were found in boggy areas with peat hummocks emerging from swampy depressions of drained lakes without any connection with the patron (Kondratyev et al., 2013). By 2017-19, the number of such large and small colonies, as well as single nests in swampy floodplains, watershed lake basins, and watershed bogs grew intensively and now the species has successfully settled on almost all landscapes of the island. Colonies along the banks of the Peschanka River are located every $2-4 \mathrm{~km}$ and number up to $300-400$ nests. The colonies are also common in the estuaries of the major rivers of the island, as well as around Peregrine Falcon nesting sites. The colony in the Peschanka Delta remains the largest in the world with its current size estimated at approximately 70,000 breeding pairs (Kondratyev et al., 2019).

\section{Birds of Prey}

The density of Rough-legged Hawk increased significantly during our study. According to the available historical data of the late 19th to early 20th centuries (Morozov and Syroechkovsky, 2004), the species was absent on the island. The first record of Rough-legged Hawk on Kolguev Island was in 1994 during the expedition "Tundra Ecology-94," however, according to information from local residents, it has been annually observed as a rare species (Morozov and Syroechkovsky, 2004). In 1994, single possible breeding events were also registered (Wiklund et al., 1995). Therefore, Rough-legged Hawks started regularly breeding on Kolguev Island only in the 1990s. Since 2006, this species has been breeding annually on Kolguev. Pokrovsky et al. (2015) reported that up until 2013, Rough-legged Hawks nested on Kolguev at a relatively stable and low density $\left(2.6 \pm 0.7\right.$ pairs $\left./ 100 \mathrm{~km}^{2}\right)$. The relatively stable productivity of Rough-legged Hawks on Kolguev over the years contrasts with the dynamics of the species in most ecosystems with small rodents, where the density and productivity of hawks track the density of rodents. The density of breeding Rough-legged Hawks observed on Kolguev was similar to that observed in other areas with low densities of small rodents (Sokolov, 2002; Mechnikova, 2009; Tast et al., 2010). However, in areas with high amplitude rodent cycles, breeding densities during peak years can be up to 10 times higher (Tast et al., 2010).

While in 2006-13 the mean density of Rough-legged Hawks was $2.6 \pm 0.7$ pairs $/ 100 \mathrm{~km}^{2}$ (Pokrovsky et al., 2015), it more than doubled to a mean density of 6.0 nesting pairs $/ 100 \mathrm{~km}^{2}$ in $2017-19$. The main prey of Rough-legged Hawks on Kolguev are Willow Ptarmigan and three goose species: Greater White-fronted Goose, Tundra Bean Goose, and Barnacle Goose (Pokrovsky et al., 2015). The increase in the numbers of Rough-legged Hawks can be explained by the increase in the numbers of geese and the recovery of the Willow Ptarmigan population after the depression in recent years. Pokrovsky et al. (2015) showed that in 2013 more than $60 \%$ of the identified prey items of Rough-legged Hawk in the central part of the island were Greater Whitefronted and Tundra Bean Geese (mainly goslings), while the proportion of Barnacle Goose was six times lower. However, since then, the number of Barnacle Goose has been rapidly increasing in the central part of the island (Kondratyev et al., 2019), which could result in an increase in the proportion of the species in the diet of Rough-legged Hawk and lead to an increase in hawk numbers.

\section{CONCLUSIONS}

Our study shows the importance of Kolguev Island for many Arctic breeding birds. There are extremely high nesting densities of many species of geese, waders, passerines, and Willow Ptarmigan on the island. Ornithological studies on the island have been known since the end of the 19th century. Since the end of the 20 th century, studies have been carried out every few years and almost annually in the last decade. As a result of these studies, important data were obtained, reflecting the dynamics of the species inhabiting the island and their abundance over more than a century, which is quite rare for the Russian Arctic. During this period, trends towards an increase in the proportion of widespread and Siberian species with a decrease in the proportion of Arctic species (according to Shtegman, 1938) were shown. A northward shift of the range of bird species in the Arctic has been reported in recent decades for numerous species (reviewed in Lappo et al., 2012; Ganter and Gaston, 2013). Our study has shown some further changes in species abundance on Kolguev. In contrast to the increase of the Barnacle Goose population and high numbers of Greater Whitefronted Goose and Tundra Bean Goose populations, the population density of some waders (Black-bellied Plover, Dunlin, Ruddy Turnstone) is decreasing. This finding reflects the general trend reported by Smith et al. (2020) that over half of all circumpolar Arctic wader taxa are declining, and almost half of all waterfowl are increasing, which has fostered a shift in community composition in some locations. There is also an increase in the population density of Rough-legged Hawk at the expense of the high breeding density of geese, despite the complete absence of rodents. But to confirm these trends, the research on Kolguev needs to be continued. Our data can form the basis for further monitoring programs on the island. Studies of Kolguev ecosystems have highlighted the high international conservation value of the island due to the high breeding density of many bird species and provided a unique case of monitoring of a lemming-free ecosystem, examples of which are quite rare in the Arctic. 


\section{ACKNOWLEDGEMENTS}

We would like to express our sincere gratitude to all the participants who took part in collecting materials and conducting ornithological observations during the expeditions of 2006-19. Bugrino village residents Albert Ardeev and Alexey Ardeev regularly provided us with valuable information on the distribution of birds and provided all kinds of assistance during our stay on the island. The administration of the Nenets Autonomous Region provided substantial assistance in the preparation and conduct of the expeditions. The organizational and logistic support of Andrey Vokuev, a resident of Naryan-Mar, was also irreplaceable during these years. Financial and organizational support for the expeditions was provided by various grants, funds, and projects, such as the UNEP/GEF International Project ECORA 2006-2008, Vogelschutz-Komitee, Conservation Bundesamtfür Naturschutz, BfN, FKZ 3510861000 (Bestandsveränderungen von Zugvögeln des Wattenmeeres 2010-2013), and FKZ 3516821500 (Meeresenten 2017-2019). This work was supported by the Russian Ministry of Science and Higher Education (Project No. AAAA-A19-119021990093-8) and by the Russian Foundation for Basic Research (Grant 18-05-60057 Arctic “The 'greening' of tundra as a driver of Arctic biota dynamics").

\section{REFERENCES}

Alisauskas, R.T., Charlwood, J.W., and Kellett, D.K. 2006. Vegetation correlates of the history and density of nesting by Ross's Geese and Lesser Snow Geese at Karrak Lake, Nunavut. Arctic 59(2):201-210.

https://doi.org/10.14430/arctic342

Andreev, A. 1988. The ten-year cycle of the willow grouse of Lower Kolyma. Oecologia 76(2):261 -267. https://doi.org/10.1007/BF00379960

Anufriev, V.V. 2006. Орнитофауна островов Печорского моря [Avifauna of islands of the Pechora Sea]. Vestnik Pomorskogo Universiteta. Seriya estestvennye i tochnye nauki 1(9):70-79.

- 2010. Особенности экологии белой куропатки (Lagopus lagopus) Большеземельской тундры [Ecological aspects of Willow Ptarmigan (Lagopus lagopus) in Bolshezemelskaya tundra]. Hunting Bulletin 7(2):170-172.

- 2012а. Ресурсы охотничьих животных островов Колгуев и Вайгач [Resources of game species of Kolguev and Vaygach islands]. In: Shiryaev V.V., ed. Современные проблемы природопользования, охотоведения и звероводства [Recent problems of nature use, game biology and fur farming]. Proceedings of the International Scientific and Practical Conference dedicated to the 90th anniversary of Russian Research Institute of Game Management and Fur Farming, 22-25 May. Kirov: VNIIOZ RAS. 209-210.

. 2012b. Сравнительная оценка населения птиц и млекопитающих Большеземельской тундры и Гыданского полуострова [Comparative assessment of bird and mammal populations of Bolshezemelkaya tundra and Gydan Peninsula]. Bulletin of Northern (Arctic) Federal University. Series of Natural and Exact Science 4:41-49.
Bates, D., Mächler, M., Bolker, B.M., and Walker, S.C. 2015. Fitting linear mixed-effects models using lme4. Journal of Statistical Software 67(1): 1-48. https://doi.org/10.18637/jss.v067.i01

Benjamini, Y., and Hochberg, Y. 1995. Controlling the false discovery rate: A practical and powerful approach to multiple testing. Journal of the Royal Statistical Society: Series B (Methodological) 57(1):289-300. https://doi.org/10.1111/j.2517-6161.1995.tb02031.x

Bennett, G.F., Montgomerie, R., and Seutin, G. 1992. Scarcity of Haematozoa in birds breeding on the Arctic tundra of North America. The Condor 94(1):289-292. https://doi.org/10.2307/1368821

Bergerud, A.T. 1970. Population dynamics of the Willow Ptarmigan Lagopus lagopus alleni L. in Newfoundland 1955 to 1965 . Oikos 21(2):299-325.

https://doi.org/10.2307/3543687

Blew, J., Günther, K., Hälterlein, B., Kleefstra, R., Laursen, K., and Scheiffarth, G. 2016. Trends of migratory and wintering waterbirds in the Wadden Sea 1987/1988-2013/2014. Wadden Sea Ecosystem No. 37. Wilhelmshaven, Germany: Common Wadden Sea Secretariat, Joint Monitoring Group of Migratory Birds in the Wadden Sea.

Bogdanovskaya-Gienef, I.D. 1938. Природные условия и оленьи пастбища острова Колгуева [Natural conditions and reindeer pastures of Kolguev Island]. Materials of the Polar Agriculture, Animal Stock and Hunting Husbandry Research Institute 2:5-161.

Buturlin, S.A. 1903. Предварительный краткий отчет о поездке на остров Колгуев летом 1902 года [A preliminary brief report of the trip to Kolguev Island in the summer 1902]. Proceedings of the Imperial Russian Geographical Society 39(3):228-248.

Byrkjedal, I., and Kålås, J.A. 2012. Censuses of breeding birds in a South Norwegian Arctic-alpine habitat three decades apart show population declines in the most common species. Ornis Norvegica 35:43-47. https://oi.org/10.15845/on.v35i0.288

Crawley, M.J. 2007. The R Book. Chichester, United Kingdom: John Wiley \& Sons. https://doi.org/10.1002/9780470515075

Davis, S.E., Nager, R.G., and Furness, R.W. 2005. Food availability affects adult survival as well as breeding success of Parasitic Jaegers. Ecology 86(4):1047-1056.

https://doi.org/10.1890/04-0989

Duncan, D.B. 1955. Multiple range and multiple $F$ tests. Biometrics 11(1): $1-42$.

https://doi.org/10.2307/3001478

Ebbinge, B.S. 1991. The impact of hunting on mortality rates and spatial distribution of geese wintering in the Western Palearctic. Ardea 79(2):197-210.

Exo, K.-M., Hillig, F., and Bairlein, F. 2019. Migration routes and strategies of Grey Plovers (Pluvialis squatarola) on the East Atlantic Flyway as revealed by satellite tracking. Avian Research 10(1): 28.

https://avianres.biomedcentral.com/articles/10.1186/s40657019-0166-5 
Fox, A.D., and Leafloor, J.O., eds. 2018. A global audit of the status and trends of Arctic and Northern Hemisphere goose populations (Component 2: Population accounts). Akureyri, Iceland: Conservation of Arctic Flora and Fauna (CAFF) International Secretariat. http://hdl.handle.net/11374/2162

Fox, A.D., Nielsen, R.D., and Petersen, I.K. 2019. Climate-change not only threatens bird populations but also challenges our ability to monitor them. Ibis 161(2):467-474. https://doi.org/10.1111/ibi.12675

Ganter, B., and Gaston, A.J. 2013. Birds. In: Meltofte, H., Josefson, A.B., and Payer, D., eds. Arctic biodiversity assessment 2013: Status and trends in Arctic biodiversity. Akureyri, Iceland: CAFF. $142-180$.

Gavrilo, M.V. 1991. Белощекая казарка на острове Колгуев [Barnacle Goose on Kolguev Island]. Proceedings of the 10th All-Union Ornithological Conference. Part 2, Vol. 1: 128. Minsk, Russia: Nauka.

Gerlach, B., Dröschmeister, R., Langgemach, K., Borkenhagen, K., Busch, M., Hauswirth, M., Heinicke, T., et al. 2019. Vögel in Deutschland: Übersichten zur Bestandssituation [Birds of Germany: Overview of stock status]. Münster, Germany: DDA, BfN, and LAG VSW.

Gilg, O., Sittler, B., and Hanski, I. 2009. Climate change and cyclic predator-prey population dynamics in the high Arctic. Global Change Biology 15(11):2634-2652. https://doi.org/10.1111/j.1365-2486.2009.01927.x

Gilg, O., Kovacs, K.M., Aars, J., Fort, J., Gauthier, G., Grémillet, D., Ims R.A., et al. 2012. Climate change and the ecology and evolution of Arctic vertebrates. Annals of the New York Academy of Sciences 1249(1):166-190. https://doi.org/10.1111/j.1749-6632.2011.06412.x

Gladkov, N.A. 1954. Семейство Трясогузковые Motacillidae [Family Motacillidae]. In: Dementiev, G.P., and Gladkov, N.A., eds. Birds of the Soviet Union. Vol. 5. Moscow: Sovetskaya nauka. Vol. 5:594-691.

Glazov, M.V. 1998. Условия гнездования куликов в тундрах России в 1997 году. На острове Колгуеве [Nesting conditions of waders in the Russian tundra in 1997 on Kolguev Island]. Informational Materials of RWG 11: 29.

Gribova, S.A. 1980. Тундры [Tundra]. In: Gribova et al., eds. Растительность европейской части СССР [Vegetation of the European Part of the USSR]. Leningrad: Nauka. 29-42.

Hörnfeldt, B. 1978. Synchronous population fluctuations in voles, small game, owls, and tularemia in northern Sweden. Oecologia 32:141-152. https://doi.org/10.1007/BF00366068

Hornman, M., Hustings, F., Koffijberg, K., Kleefstra, R., Klaassen, O., van Winden, E., SOVON Ganzen-en Zwanenwerkgroep, and Soldaat, L. 2012. Watervogels in Nederland in 2009/2010 [Waterbirds in the Netherlands 2009/2010]. SOVON-rapport 2012/02, Waterdienst-rapport BM 12.06. Nijmegen, The Netherlands: SOVON Vogelonderzoek Nederland. https://www.sovon.nl/sites/default/files/doc/Rap201202watervogelsLR.pdf
Ims, R.A., and Fuglei, E. 2005. Trophic interaction cycles in tundra ecosystems and the impact of climate change. Bioscience 55(4):311-322.

https://doi.org/10.1641/0006-3568(2005)055[0311:TICITE]2.0. $\mathrm{CO} ; 2$

Ims, R.A., Henden, J.-A., and Killengreen, S.T. 2008. Collapsing population cycles. Trends in Ecology \& Evolution 23(2):79-86. https://doi.org/10.1016/j.tree.2007.10.010

Kausrud, K.L., Mysterud, A., Steen, H., Vik, J.O., Østbye, E., Cazelles, B., Framstad, E., et al. 2008. Linking climate change to lemming cycles. Nature 456:93-97. https://doi.org/10.1038/nature07442

Kleefstra, R., Hornman, M., Bregnballe, T., Frikke, J., Günther, K., Hälterlein, B., Körber, P., Ludwig, J., and Scheiffarth, G. 2019. Trends of migratory and wintering waterbirds in the Wadden Sea 1987/1988-2016/2017. Wadden Sea Ecosystem No. 39. Wilhelmshaven, Germany: Common Wadden Sea Secretariat, Joint Monitoring Group of Migratory Birds in the Wadden Sea.

Kondratyev, A., Zaynagutdinova, E., and Kruckenberg, H. 2012. Современный статус и биология гусей на острове Колгуеве [Current status and biology of geese on Kolguev Island]. Casarca 15(2):31-71.

_. 2013. Barnacle Goose Branta leucopsis abundance on Kolguev Island - current status and history of population growth. Wildfowl 63:56-71.

Kondratyev, A.V., Glazov, P.M., Zaynagutdinova, E.M., Loshchagina, J.A., Anisimov, Yu.A., and Pokrovskaya, O.B. 2019. Современное состояние и динамика орнитофауны острова Колгуев [Current state and dynamics of the avifauna of Kolguev Island]. Ornithologia 43:24-44.

Koreisha, M.M. 2000. Остров Колгуев [Kolguev Island]. Journal of Geocryology 1:69-91.

Krasnov, Yu.V., Gavrilo, M.V., Strøm, H., and Shavykin, A.A. 2008. О позднелетнем распределении птиц на острове Колгуев и в его прибрежных акваториях [Distribution of birds on Kolguev Island and adjacent Barents Sea areas during late summer]. Ornithologia 35:83-96.

Kruckenberg, H., Kondratyev, A., Zöckler, C., Zaynagutdinova, E., and Mooij, J.H. 2012. Breeding waders on Kolguev Island, Barents Sea, N Russia, 2006-2008. Wader Study Group Bulletin 119(2):102-113.

Kuzyakin, V.A., and Chelintsev, N.G. 2005. Учет охотничьих животных: учебное пособие [Counts of hunting animals: Study guide]. Moscow: Publishing house of the Russian State Agrarian Correspondence University.

Kutz, S.J., Hoberg, E.P., Polley, L., and Jenkins, E.J. 2005. Global warming is changing the dynamics of Arctic host-parasite systems. Proceedings of the Royal Society B: Biological Sciences 272(1581):2571-2576. https://doi.org/10.1098/rspb.2005.3285

Lappo, E.G., Tomkovich, P.S., and Syroechkovskiy, E. 2012. Атлас гнездящихся куликов Российской Арктики [Atlas of breeding waders in the Russian Arctic]. Moscow: UF Ofsetnaya Pechat.

Lenth, R.V. 2016. Least-squares means: The R package lsmeans. Journal of Statistical Software 69(1): 1-33. https://doi.org/10.18637/jss.v069.i01 
MacMillan, D., Hanley, N., and Daw, M. 2004. Costs and benefits of wild goose conservation in Scotland. Biological Conservation 119(4):475-485.

https://doi.org/10.1016/j.biocon.2004.01.008

Makarova, O.L., Anufriev, V.V., Babenko, A.B., Bizin, M.S., Glazov, P.M., Kolesnikova A.A., Marusik, Yu.M. et al. 2019. Фауна Восточно-Европейских тундр: вклад “сибирских" видов [Fauna of the East European tundra: The input of "Siberian" species]. Bulletin of North-Eastern Scientific Center Russia Academy of Sciences. Far East Branch 1:59-71.

Marchowski, D., Jankowiak, Ł., Wysocki, D., Ławicki, Ł., and Girjatowicz, J. 2017. Ducks change wintering patterns due to changing climate in the important wintering waters of the Odra River Estuary. PeerJ 5: e3604.

https://doi.org/10.7717/peerj.3604

Marchowski, D., Ławicki, Ł., Guentzel, S., Kaliciuk, J., and Kajzer, Z. 2018. Long-term changes in the numbers of waterbirds at an important European wintering site. Acta Biologica 25:111-122.

https://doi.org/10.18276/ab.2018.25-09

McKinnon, L., Smith, P.A., Nol, E., Martin, J.L., Doyle, F.I., Abraham, K.F., Gilchrist, H.G., Morrison, R.I.G., and Bêty, J. 2010. Lower predation risk for migratory birds at high latitudes. Science 327(5963):326-327.

https://doi.org/10.1126/science.1183010

Mechnikova, S.A. 2009. Хищные птицы Южного Ямала: особенности размножения и динамика численности [Raptors of the southern Yamal: Breeding ecology and population dynamics]. Moscow: Moscow State Pedagogical University.

Meltofte, H. 2001. Wader population censuses in the Arctic: Getting the timing right. Arctic 54(4):367-376.

https://doi.org/10.14430/arctic794

Meredith, M., Sommerkorn, M., Cassotta, S., Derksen, C., Ekaykin, A., Hollowed, A., Kofinas, G., et al. 2019. Polar regions. In: Pörtner, H.-O., Roberts, D.C., Masson-Delmotte, V., Zhai, P., Poloczanska, E., Mintenbeck, K., Tignor, M., et al., eds. IPCC special report on the ocean and cryosphere in a changing climate. IPCC, WMO, UNEP. 203-320.

https://www.ipcc.ch/site/assets/uploads/sites/3/2019/11/04 SROCC_TS_FINAL.pdf

Mineev, O.Y., and Mineev, Y.N. 2017. Динамика численности и распределение белой куропатки в восточноевропейских тундрах России [Роpulation dynamics and distribution of the Willow Ptarmigan in the eastern European tundra of Russia]. Bulletin of the Moscow Society of Naturalists: Biological Department 122(4):8-18.

Mineev, Y.N., and Mineev, O.Y. 2009. Птицы Малоземельской тундры и дельты Печоры [Birds of Malozemelskaya tundra and the Pechora Delta]. St. Petersburg: Nauka.

- 2012. Птицы Большеземельской тундры и Югорского полуострова [Birds of Bolshezemelskaya tundra and the Yugor Peninsula]. St. Petersburg: Nauka.

Morozov, V.V., and Syroechkovsky, E.E. 2004. Материалы к познанию орнитофауны острова Колгуева [Materials on the knowledge of the avifauna of Kolguev Island]. Ornithologia 31:9-50.
Moss, R., and Watson, A. 2001. Population cycles in birds of the grouse family (Tetraonidae). Advances in Ecological Research 32:53-111.

Myrberget, S. 1974. Variations in the production of the Willow Grouse Lagopus lagopus (L.) in Norway, 1963-1972. Ornis Scandinavica 5(2):163-172. https://doi.org/10.2307/3676059

Nagy, S., Flink, S., and Langendoen, T. 2014. Waterbird trends 1988-2012: Results of trend analyses of data from the International Waterbird Census in the African-Eurasian Flyway. Ede, The Netherlands: Wetlands International.

Nilsson, L., and Haas, F. 2016. Distribution and numbers of wintering waterbirds in Sweden in 2015 and changes during the last fifty years. Ornis Svecica 26(1):3-54.

https://doi.org/10.34080/os.v26.21854

Pearson, H.J. 1896. Notes on birds observed in Russian Lapland, Kolguev, and Novaya Zemlya, in 1895. Ibis, 38(2):199-225. https://doi.org/10.1111/j.1474-919X.1896.tb06987.x

Pleske, T.D. 1928. Birds of the Eurasian tundra. Memoir 6. Boston, Massachusetts: Boston Society of Natural History.

Pokrovsky, I., Ehrich, D., Ims, R.A., Kondratyev, A.V., Kruckenberg, H., Kulikova, O., Mihnevich, J., Pokrovskaya, L., and Shienok, A. 2015. Rough-legged buzzards, Arctic foxes and red foxes in a tundra ecosystem without rodents. PLOS One 10: e0118740. https://doi.org/10.1371/journal.pone.0118740

Pokrovsky, I., Kölzsch, A., Sherub, S., Fiedler, W., Glazov, P., Kulikova, O., Wikelski, M., and Flack, A. 2021. Longer days enable higher diurnal activity for migratory birds. Journal of Animal Ecology. Online version before inclusion in an issue. https://doi.org/10.1111/1365-2656.13484

Ponomareva, T.S. 1990. Белощекая казарка. Новое гнездовое поселение в окрестностях о. Колгуева [Barnacle Goose: New breeding colony in the surroundings of Kolguev island]. In: Amirkhanov, A.M., ed., Итоги изучения редких животных (Материалы к Красной книге) [Results of rare species study (Materials for the Red Data Book)]. Moscow: Central Research Laboratory of Hunting Control Headquarter of Russian Federation. 81-84.

Potapov, G.S., and Spitsyn, V.M. 2019. Аннотированный список птиц, отмеченных на острове Колгуев в августе 2018 года [Annotated list of birds recorded on Kolguev Island in August 2018]. Russian Ornithological Journal 28(1760):1831 - 1835.

Ravkin, E.S., and Chelintsev, N.G. 1990. Методические рекомендации по комплексному маршрутному учёту птиц [Methodical recommendations for integrated route counting of birds]. Moscow: All-Union Scientific Research Institute for Nature Conservation and Reserve Management of the USSR State Committee for Nature Protection.

R Core Team. 2021. R: A language and environment for statistical computing. Vienna, Austria: R Foundation for Statistical Computing. https://cran.r-project.org/

Reeves, R.R., Ewins, P.J., Agbayani, S., Heide-Jørgensen, M.P., Kovacs, K.M., Lydersen, C., Suydam, R., et al. 2014. Distribution of endemic cetaceans in relation to hydrocarbon development and commercial shipping in a warming Arctic. Marine Policy 44:375-389.

https://doi.org/10.1016/j.marpol.2013.10.005 
Ryabitsev, V.K. 2001. Птицы Урала, Приуралья и Западной Сибири [Birds of the Urals, Cisurals and Western Siberia: Reference guide]. Ekaterinburg: Ural University Press.

Schekkerman, H., Tulp, I., Piersma, T., and Visser, G.H. 2003. Mechanisms promoting higher growth rate in Arctic than in temperate shorebirds. Oecologia 134(3):332-342.

https://doi.org/10.1007/s00442-002-1124-0

Schindler, D.W., and Smol, J.P. 2006. Cumulative effects of climate warming and other human activities on freshwaters of Arctic and subarctic North America. Ambio 35(4):160- 168. https://doi.org/10.1579/0044-7447(2006)35[160:ceocwa]2.0. co;2

Seebohm, H. 1880. Siberia in Europe: A visit to the valley of the Petchora, in North-East Russia; with description of the natural history, migration of birds, etc. London, John Murray. https://doi.org/10.5962/bhl.title.56583

Shtegman, B.К. 1938. Основы орнитогеографического деления Палеарктики [Principles of ornithogeographical division of Palearctic]. In: Zernov S.A. ed. Фауна СССР Птицы [Fauna of USSR. The Birds 1(2)]. Moscow and Leningrad: Publishing House of the Academy of Sciences of the USSR.

Smith, P.A., McKinnon, L., Meltofte, H., Lanctot, R.B., Fox, A.D., Leafloor, J.O., Soloviev, M., et al. 2020. Status and trends of tundra birds across the circumpolar Arctic. Ambio 49:732- 748 . https://doi.org/10.1007/s13280-019-01308-5

Smol, J.P., Wolfe, A.P., Birks, H.J.B., Douglas, M.S.V., Jones, V.J., Korhola, A., Pienitz, R., et al. 2005. Climate-driven regime shifts in the biological communities of Arctic lakes. Proceedings of the National Academy of Sciences 102(12):4397-4402. https://doi.org/10.1073/pnas.0500245102

Sokolov, A.A. 2002. Функциональные связи мохноногого канюка (Buteo lagopus) и мелких грызунов южных кустарниковых тундр Ямала [Functional connections between Rough-legged Buzzards (Buteo lagopus) and small rodents in the southern shrub tundra of Yamal]. Ekaterinburg: Institute of Plant and Animal Ecology.

Stroud, D.A., Davidson, N.C., West, R., Scott, D.A., Haanstra, L., Thorup, O., Ganter, B., and Delany, S., comp. 2004. Status of migratory wader populations in Africa and Western Eurasia in the 1990s. Thetford, United Kingdom: International Wader Studies 15.

Tast, J., Kaikusalo, A., and Lagerström, M. 2010. Breeding biology of Rough-legged Buzzards Buteo lagopus at Kilpisjärvi, NW Finnish Lapland, in relation to rodent cycles. Kilpisjärvi Notes 22:1-9.

Tolmachev, A.I. 1927. К авифауне острова Колгуева [On the avifauna of Kolguev Island]. Annual Issue of the Zoological Museum of the USSR Academy of Sciences 28:355-365.

Trevor-Battye, A.B.R. 1895. Ice-bound on Kolguev. A chapter in the exploration of Arctic Europe, to which is added a record of the natural history of the island. London: A. Constable and Co. 458 p.

https://doi.org/10.5962/bhl.title.55094
Van der Wal, R. 2006. Do herbivores cause habitat degradation or vegetation state transition? Evidence from the tundra. Oikos 114(1):177-186. https://doi.org/10.1111/j.2006.0030-1299.14264.x

Van Eerden, M.R., Drent, R.H., Stahl, J., and Bakker, J.P. 2005. Connecting seas: Western Palaearctic continental flyway for water birds in the perspective of changing land use and climate. Global Change Biology 11(6):894-908. https://doi.org/10.1111/j.1365-2486.2005.00940.x

Van Roomen, M., Nagy, S., Foppen, R., Dodman, T., Citegetse, G., and Ndiaye, A. 2015. Status of coastal waterbird populations in the East Atlantic Flyway. With special attention to flyway populations making use of the Wadden Sea. Leeuwarden, The Netherlands: Programme Rich Wadden Sea; Nijmegen, The Netherlands: Sovon; Wageningen, The Netherlands: Wetlands International; Cambridge, United Kingdom: BirdLife International; Wilhelmshaven, Germany: Common Wadden Sea Secretariat.

https://www.waddensea-worldheritage.org/sites/default/ files/2015_Status\%20coastal\%20birds.pdf

Van Roomen, M., van Turnhout, C., Blew, J., Koffijberg, K., Nagy, S., Citegetse, G., and Foppen, R. 2017. East Atlantic Flyway. In: Kloepper, S., Baptist, J.M., Bostelmann, A., Busch, J.A., Buschbaum, C., Gutow, L., Janssen, G., et al., eds. Wadden Sea quality status report 2017. Wilhelmshaven, Germany: Common Wadden Sea Secretariat.

Watson, A., and Moss, R. 1979. Population cycles in the Tetraonidae. Ornis Fennica 56(2-3):87-109.

Wetlands International. 2020. Waterbird population estimates. Wageningen, The Netherlands: Wetlands International. http://wpe.wetlands.org

Wiklund, C.G., Isakson, E., and Kjellen, N. 1995. The distribution of avian lemming predators on the Arctic tundra of northern Russia. In: Grönland, E., and Melander, O., eds. SwedishRussian Tundra Ecology Expedition 94: A cruise report. Stockholm: Swedish Polar Research Secretariat. 191-196.

Zhitkov, B.M., and Buturlin, S.A. 1901. По северу России: Отчет Императорскому обществу любителей естествознания, антропологии и этнографии по командировке летом 1900 г. в Архангельскую губернию и на острова Колгуев и Новую землю [In the north of Russia: Report to the Imperial Society of Fanciers of Natural Science, Anthropology and Ethnography on a mission in the summer of 1900 to the Arkhangelsk Governorate and to the Kolguev Island and Novaya Zemlya]. Moscow: Partnership of A.I. Mamontov's printing house. 29-206.

Zuur, A.F., Ieno, E.N., Walker, N.J., Saveliev, A.A., and Smith, G.M. 2009. Mixed effects models and extensions in ecology with R. New York: Springer Nature. https://doi.org/10.1007/978-0-387-87458-6

Zuur, A.F., Ieno, E.N., and Elphick, C.S. 2010. A protocol for data exploration to avoid common statistical problems. Methods in Ecology and Evolution 1(1):3-14. https://doi.org/10.1111/j.2041-210X.2009.00001.x 